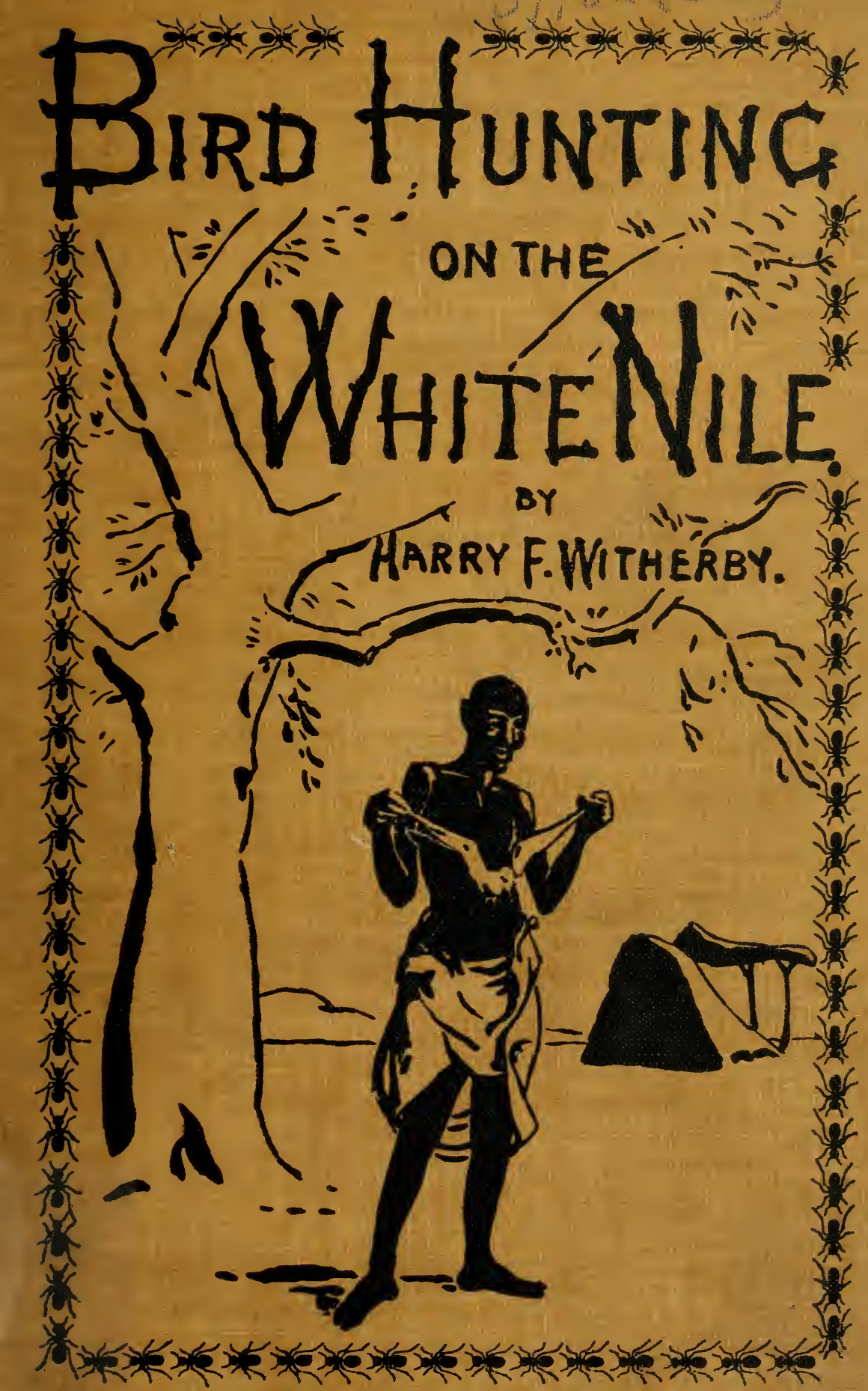







\section{BIRD HUNTING}

ON THE

WHITE NILE. 




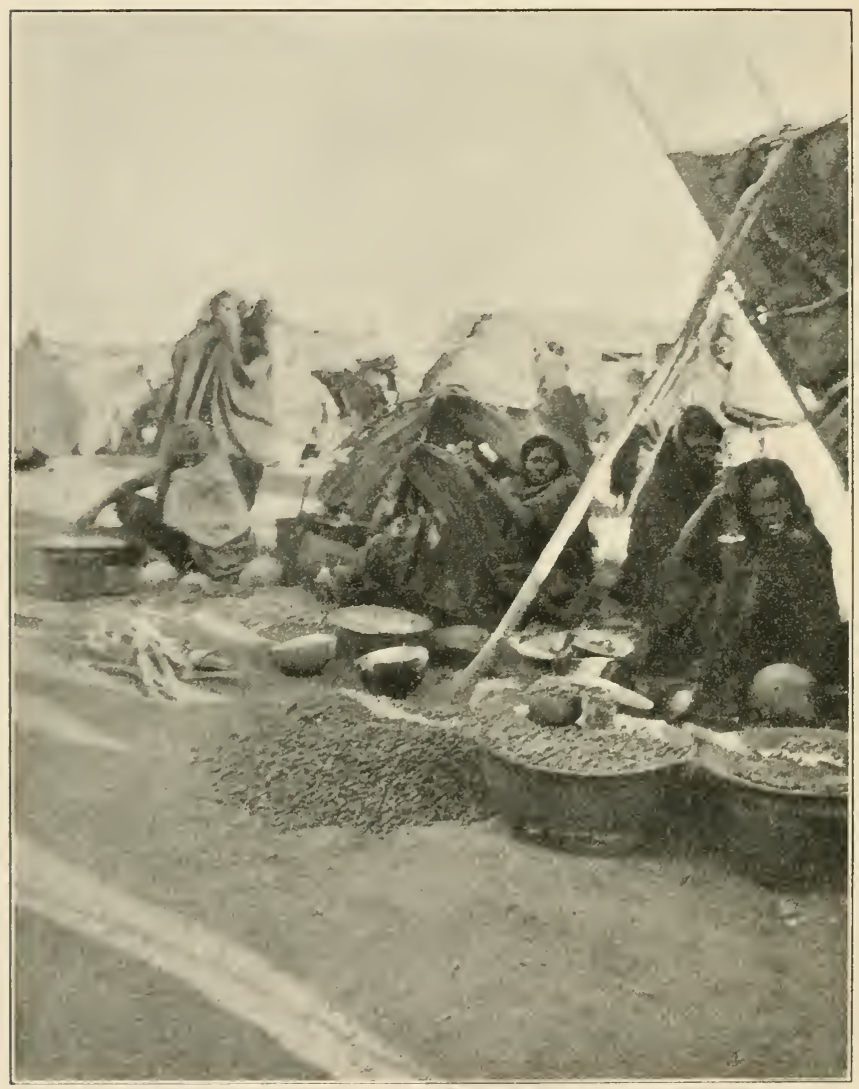

A M.IRKET SCENE AT OMDERMIX. 


\title{
BIRD HUNTING
}

\author{
ON THE

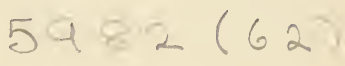

WHITE NILE

$\times 599162$

A NATURALIST'S EXPERIENCES IN THE SOUDAN.

BY

HARRY F. WITHERBY,

Fellow of the Zoological Society; Member of the British Ornithological Union; Author of

"Treo Months on the Guadalquiver," etc.

迎 $\mathfrak{a} \mathfrak{n} \mathfrak{d} \mathfrak{n}$ :

THE OFFICE OF “KNOWLEDE,” 326, High Holmorn. 
$x-101<3 k 1$ 


\section{P REFACE.}

THE journey, of which this little book forms a endeavouring to add to our knowledge of the birds and beasts of the Soudan. Birds, being my special delight, received most attention, and I make no excuse for the amount of space occupied in discussing them in the following pages. I have added in an appendix a full list of the birds observed or collected, but for a complete account of them I must refer the reader to the Ibis for 1901, pp. 237-278. Of the animals, owing to my ignorance, I have very little to say. The late Dr. John Anderson and Mr. W. E. de Winton, who had been working at the fauna of Egypt for a long time, were very anxious that I should make a collection of the mammals inhabiting the country about Khartoum. Accordingly I provided myself with all the necessary apparatus to capture and preserve animals, and hoping to find many, I took an extra collector to help with this part of the work. The results, however, were 
decidedly disappointing. Mammals were exceedingly scarce in the district, and consequently our collection was very small. Mr. de Winton, who worked out the collection, has very kindly provided me with a list of the species represented, and as the list has not appeared elsewhere, I have printed it here. Notwithstanding the small number of species found, three of them-a bat, a hare and a mouse-proved to be unknown, a fact which clearly demonstrates how meagre is our linowledge of the small mammals of Egypt. Much of our ignorance in this respect will undoubtedly be dispelled by the publication of the second volume of The Fauna of Egypt by the late Dr. Anderson. This volume will deal with the small mammals, and will be completed shortly by Mr. de Winton.

The journey was made during the driest montlis of a very dry year in the Soudan, and although such a season brought many disadvantages, it was in one sense a favourable time, because hot dry countries are, as a rule, visited during the cooler months, when the vegetation completely changes the scenery and when the human and animal populations exist under altogether different circumstances from those noticed by us.

With the help of many kind friends, both at Cairo and at Omdurman, I was able to make all preparations 
very quickly, and had it not becn for the courteous and generous aid and advice of the Sirdar, Sir F. Reginald Wingate, and the officials in Omdurman, a great deal of time would have been wasted in getting together a caravan.

The great dry heat which we encountered played sad havoc with photographing apparatus, and all my own exposures were complete failures.

Mr. C. F. Camburn, who accompanied me as a taxidermist, was more fortunate, and he has very kindly allowed me to make use of his photographs. Reproductions from these have provided the book with most of its illustrations, but $I$ am much indebted also to Mr. A. F. R. Wollaston, who visited the Soudan in 1901 , for the photograph reproduced in the frontispiece, and for those appearing on pages 25, 29 and 106. For the several wash drawings I have to thank my father, Mr. H. Forbes Witherby, who copied them with great care from my photographs.

The several chapters composing the book are reprinted, with slight alteration from Knowledge, in which journal they appeared as a series of articles in 1901, while two appendices and some illustrations have been added.

H. F. W.

Londox, January, 1902. 


\section{LIST OF ILLUSTRATIONS.}

A Market Scene at Omdurman. From a photograph ... (Frontispiece.

LitTle Maids of WAD ShalaI. Drawn from a photograph $\ldots$ I2 $^{\text {PaGe }}$

A Raft on the White Nile. Drawn from a photograph $\quad . . \quad$ I3

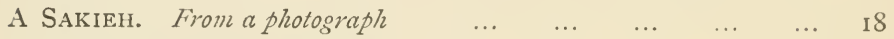

The River Bank, Omdurman. From a photograph $\quad \ldots \quad \ldots \quad 2$ I

$\begin{array}{lllllll}\text { The BazaAr at Khartoun. From a photograph .. } & \ldots & \ldots & 23\end{array}$

The Great Square in Omdurman, With the Khalifa's

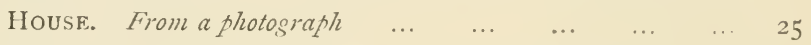

The Ruins of The Mahdi's Tomb. From a photograph $\quad \ldots \quad 27$

In the Market at OMdurMan. From a photograph $\quad \ldots \quad$... 29

$\begin{array}{lllllllll}\text { MAHOMET AT WORK. From a photograph } & \ldots & \ldots & \ldots & \ldots & 34\end{array}$

The Head Camel Max. Drawn from a photograph $\ldots . \quad \ldots \quad 36$

Sketcil Map shoiving Route and Collecting Camps _.. $3 S$

Boat Building on tile IVirite Nile. From a photograph $\quad \ldots \quad 42$

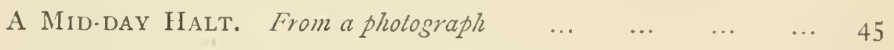

Building a Square Brick Hut. From a photograph $\ldots . .454$

A Dome-shaped Hut with a "Verandah." From a photograph 56

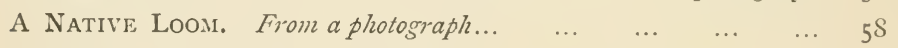

A Movable Hut made of Matting. From a photograph ... 60

$\begin{array}{llllllll}\text { The CaMp at Duem. From a photograph } & \ldots & \ldots & \ldots & \ldots & 7 \text { I }\end{array}$

$\begin{array}{lllllll}\text { The CAMp at Gerazi. From a photograph... } & \ldots & \ldots & \ldots & 75\end{array}$

$\begin{array}{llllllll}\text { Collecting Fuei.. Drawn from a photograph } & \ldots & \ldots & \ldots & 77\end{array}$

$\begin{array}{lllllllll}\text { BleEding MaHOMet. From a photograph } & \ldots & \ldots & \ldots & \ldots & \mathrm{S}_{7}\end{array}$

The "Cup" FIXed on TIIE NeCk. From a photosraph $\quad .$. S9

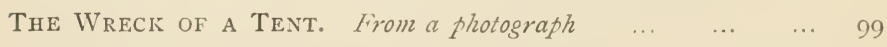

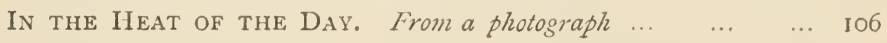




\section{CONTENTS.}

CHAP.

PAGE

I. The Desert Rallivay, Khartoun and $\begin{array}{llllll}\text { OMdDURMAN } & \ldots & \ldots & \ldots & \ldots & \text { I } 3\end{array}$

II. The River-Essential alike to Man, $\begin{array}{lllllll}\text { BEAST AND BIRD } & \ldots & \ldots & \ldots & 37\end{array}$

III. The Country and the People $\ldots$.. 50

IV. Camping and Collecting $\quad \ldots \quad \ldots \quad \ldots 65$

$\begin{array}{lllllllll}\text { V. } & \text { BIRDS } & \ldots & \ldots & \ldots & \ldots & \ldots & 78\end{array}$

VI. A DANCE, A SAND-STORM, AND A RaRE $\begin{array}{lllllll}\mathrm{BIRD} & \ldots & \ldots & \ldots & \ldots & \ldots & 9 \text { I }\end{array}$

Appendix A.-List ol the Birds Collected AND OBSERVED $\quad \ldots \quad \ldots \quad$ IO9

Appendix B.-List of the Mamials $\quad \ldots \quad$ il 3

$\begin{array}{llllllll}\operatorname{INDEX} & \ldots & \ldots & \ldots & \ldots & \ldots & \ldots & \text { I I } 5\end{array}$ 


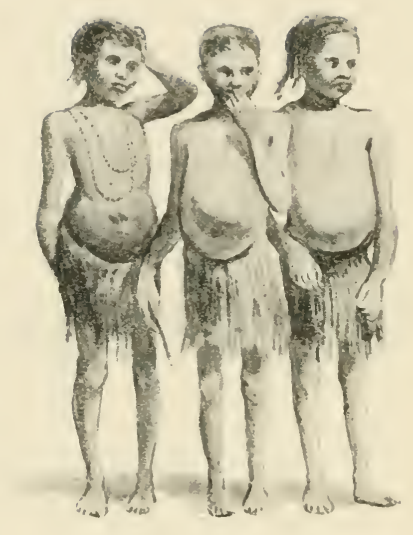

Little Maids of Wad shalai.

Draxn fiom a photogruphe. 


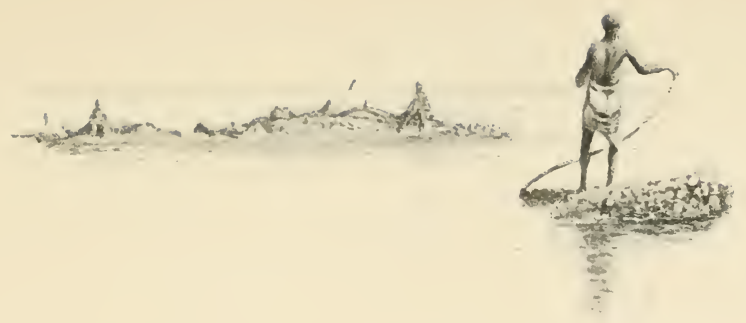

I Rajt on the White Nile.-Diann from a photogran h.

\title{
BIRD HUNTING ON TIIE WHITE NILE.
}

\author{
CHAPTER I. \\ THE DESERT RAILWAY, KHARTOUI AND \\ O.IDURILA.I.
}

HORTLY after the battle of Om Debreikat and the $\int$ death of the Khalifa Abdullahi, I found that it would be possible to travel in the Soudan. For fifteen years the country had been in the hands of powerful savage tribes, and before that time English naturalists, and especially ornithologists, had greatly neglected the Soudan, although some Germans, as for instance Brehm, Heuglin, and von Müller, had done excellent work there. The country being thus more or less new ground to English ornithologists, I was the more anxious to visit 
it, and study the birds of a small portion at all events of what had become, by right of conquest, partly English territory.

So on the last day of February, 1900, I set out from England, joining at Marseilles Messrs. E. H. Saunders and C. F. Camburn, two taxidermists who were to accompany me, and we reached Cairo on March 6th.

The journey from Cairo to Wady Halfa, even under the new conditions created by the railway, is to-day so well known that it requires but a brief description.

Instead of a long journey by boat up the Nile one can now travel from Cairo to Assouan in about 22 hours in a train, which for ease and luxury would not shame any European railway. Notwithstanding the lowness of the Nile at the time of our visit, the country from Cairo to Luxor was green and luxuriant. Camels, cattle, sheep and goats abounded, and everywhere the halfnaked people of many shades of chocolate, brown, and black were working on the land. Beyond Luxor the area of cultivated land grew gradually less. Wells, sakiehs, and shadoofs were not so frequent, villages were passed at longer intervals, and the inhabitants and their cattle became more rare in the landscape.

At Assouan we found every comfort. From this point to Omdurman we travelled under the joint Government 
of Queen Victoria and the Khedive. From Assouan a short piece of line took us to Shellal, above the first cataract, and there just opposite the Temple of Philæ we embarked upon a steamer, for no railway yet connects Assouan and Wady Halfa. And here the character of the country completely altered. 'The day before' we had travelled through a flat fertile land, whilst now we were steaming up the great river through a wild and desolate country of bare rocky hills with the merest strip of cultivated land by the edge of the river.

Here and there, however, where flat ground was available between the river bank and the foot of the hills, as for instance at Korosko, cultivation was carried on. But this was only possible with the aid of an elaborate, although primitive, system of irrigation. The sakieh, an endless chain of pitchers, somewhat in the form of a water-wheel, turned by oxen, and the shadoof, a bucket at the end of a long lever balanced by a lump of mud and worked by men, were employed in raising the water from the river above the high bank. Often two sakiehs, or four or five shadoofs one above another, or a combination of sakiehs and shadoofs, were necessary to lift the water, so low was the river and so high was the bank.

Of birds there were few in this reach of the river, but 
we noticed particularly that the hooded or grey crows* so common north of Assouan, were no longer to be seen.

The scenery was bold and impressive, and the colouring exceedingly beautiful. The blue-grey river, edged with a strip of bright green crops, and here and there a patch of dazzling white sand, led one's eye away above the bank where the desert seemed to have overflowed, and poured forth between the rocks great streams of sand of a deep rich orange colour. A background of pinkish hills, and the pure blue sky above, completed a scheme of colouring difficult to surpass. One night by the light of a brilliant moon all these colours were to be clearly distinguished, even to the pink of the distant rocks and the blue of the sky, but of such delicacy was the colouring that the whole scene became etherealised.

Our progress by the river was slow and laboured. Owing to the shallowness of the water, it being the midst of one of the driest of dry seasons, the steamer grounded and stuck continually, notwithstanding its flat bottom and shallow draught. By dint of much twisting and turning and a vast amount of hard labour on the part of our crew in poling and hauling, as well as in lightening the boat, we were not called upon to wait until the Nile rose before reaching our destination. Judging by their

\footnotetext{
* Corvus cornix, Linn.
} 
constant and hearty calls for aid from above, one could well believe that the crew ascribed this good fortune to the will of Allah and his Prophet rather than to their own exertions.

So we passed rocky Korosko, Ibrim perched on the top of a high and precipitous cliff, the wonderful rock temple Abu Simbel, and in four days from Assouan arrived at Wady Halfa.

Once a miserable village, Halfa now boasts of great workshops fitted with all the necessary machinery and appliances to keep in repair, and even to manufacture, everything connected with a railway, and the new town has been appropriately termed a miniature Crewe. From Halfa the wonderful railway which bridges 230 miles of waterless desert originated, and from Halfa to an ever increasing distance each day, with marvellous regularity during its construction, ran two trains with construction materials, and water and food for the great army of workers at railhead. In eleven months from its commencement all difficulties, and there were many, were overcome, and a railway which the best authorities had dubbed as the idea of a lunatic was completed. The journey from Halfa to Abu Hamed formerly occupied some ten days. It is now possible by this "short cut" across the desert to accomplish it in 
about as many hours. Of course the railway, both as regards permanent way and rolling stock, has vastly improved since the days of the expedition which culminated in the battle of Kerreri and the capture of

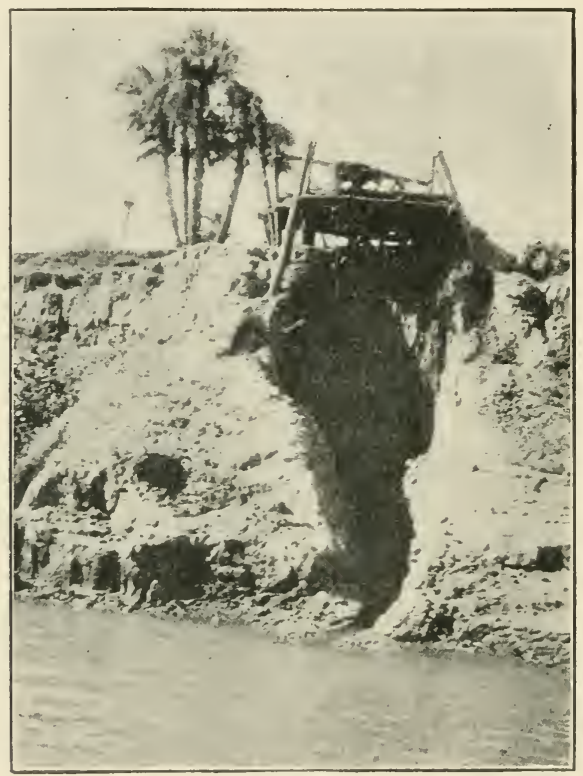

A SAKIEH.

Omdurman, and it has been extended from the Atbara, its former southern terminus, to the banks of the Blue Nile opposite Khartoum.

We travelled up in the last so-called tourist train of the season. This train was put together at Halfa, 
and many of its fittings were made there. It was somewhat devoid of cushions and elaborate fittings, which was only right in so dusty a country. But as far as comfort went one could wish for nothing better. Every necessity was on the train, cars for sleeping in, cars for dining in, cars for smoking in, an excellent cuisine, and even bath rooms. We stopped for every meal on account of the jolting of the train. At first the dust was rather a trial, but the quantity of it depends much upon the position in the train which one occupies, and also upon the direction of the wind. And after all one soon gets accustomed to eating, drinking, and wearing dust. On our journey up we accomplished the distance of 576 miles from Halfa to Halfaya on the Blue Nile, including all stoppages, in 34 hours. But on the journey down in an ordinary train, which did not stop for meals, we did the distance in 29 hours. During part of this time we ran at the rate of 40 miles an hour with an excellent American engine, one of two engines which had to be obtained from America, because at the time they were urgently required, British engineers were fully employed in a strike and could not attend to such business as building railway engines. From Halfa to Abu Hamed the railway runs across a bare desert far from the river, which here takes a great sweep. Sand, flat 
and monotonous, as far as the eye can reach, stretches out on every side. Here and there a stunted mimosa bush or a black rock rising conspicuously from the sand serves but to accentuate the loneliness and barrenness of the scene, while the mirage on every side tantalizes the eye with its shining dazzling mockery. At intervals along the single narrow track are "stations," so called, but otherwise they are nameless being only numbered one to nine. Each of these boasts of one or two tents, and some tanks of water. At some are stores of coal, and at two there are pumps, which bring up from deep below the sand that priceless water which, with "Kitchener's luck," was happed upon during the construction of the railway, when water was so valuable for men and engines that a whole month was gained by finding it. At several stations we saw ravens, $\ddagger$ and at one, some kites. What induces these birds to live in such forsaken spots, and upon what they feed, unless it is on just the scraps they can pick up round the tents, and how they get water to drink, are puzzles difficult to solve.

At Abu Hamed, with its small white-washed station house, the river was reached again, and here a few scraggy 
dôm palms, the hard round fruit of which is nicknamed Dervish bread, are a delight to the weary eye. From this point onwards the country is less uninteresting. Mimosa scrub and stunted acacia trees struggle for an existence in the gritty sand, dark rocky hills rise in the

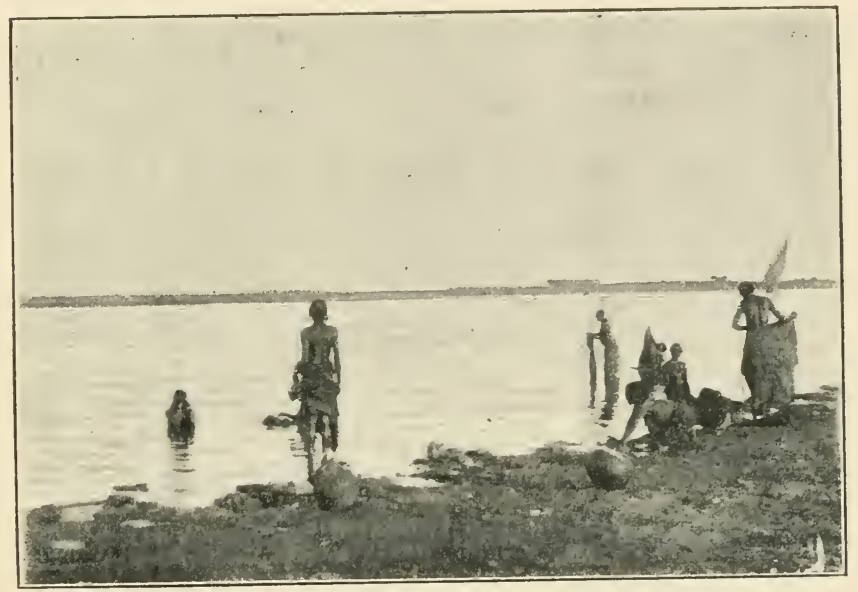

THE RIVER BANK, OMDURMAN.

distance, and a group of gazelles or a flock of small birds may now and again be seen.

We passed many a place made famous by conflictBerber, the Atbara with its fine bridge, Shendy opposite Metemma-and at length arrived at the railway's unpretending southern terminus, Halfaya, a collection of a few huts upon the sand on the north side of the Blue 
Nile almost opposite Khartoum. Here we were greeted by a dust storm, which is no unusual thing at Halfaya, a fact which has given the place a nickname of much the same sound but of a deeper significance. After considerable delay we embarked on a steamer-a dahabeah -which was to take us over to Omdurman, and upon which we were to live during our brief sojourn there. Steaming down the Blue Nile towards Omdurman we had a good view of Khartoum, which is built along the southern bank of the river amidst a grove of palm trees. It will be remembered that Khartoum was descrted, and converted into little less than a heap of ruins by the Mahdi, who set up his capital at Omdurman, a mere village at the time of the fall of Khartoum.

We are now reverting to the old order of things, and although at present nearly all the business both official and private is transacted at Omdurman, yet Khartoum will soon become again the chief town and centre of the Soudan. At the time of our visit few buildings in Khartoum were completed, but along the bank of the river houses and government offices were springing up, to say nothing of a fair-sized hotel. But the buildings to which most interest attaches are the Sirdar's palace and the Gordon Memorial College. The palace, which had been completed and occupied for some time, is a 
large and imposing though somewhat bald and ugly structure. It is built on the spot formerly occupied by Gordon's palace, and portions of the old foundations and walls have been utilized. At a little distance from the Palace a mass of scaffolding and stone showed where

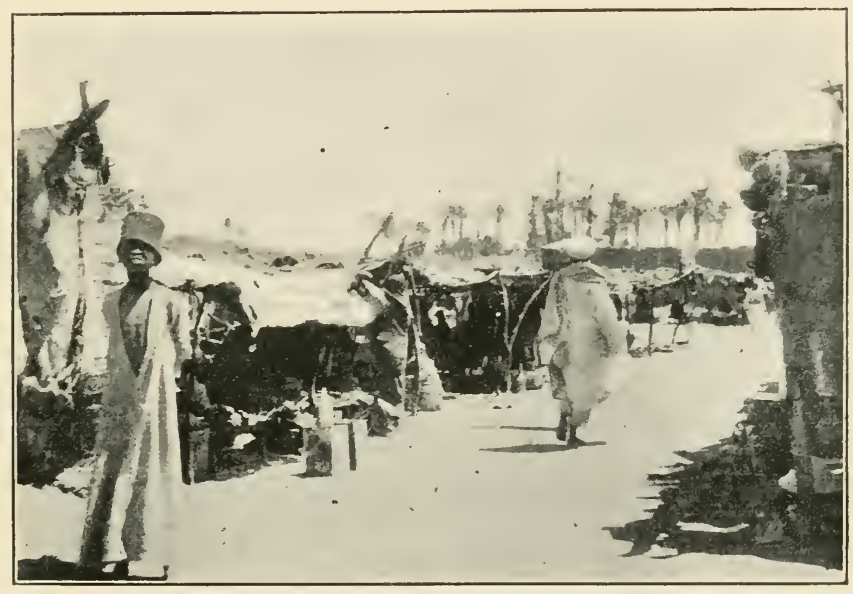

THE "BAZAAR" AT KHARTOUM.

the Gordon Memorial College was growing into existence.

As we neared Omdurman the shadow of a cloud seemed to be hanging over part of the river, the edge of the shadow being clearly defined in an uneven line even at some distance. But a glance upwards showed no cloud. The ragged line which seemed to mark where the shadow ended and the sunlight began was in reality the point 
at which the Blue Nile, with its clear dark blue waters, joined with the White Nile, the waters of which are heavily charged with sand and have a whitish appearance. As we passed over the line of junction, the idea of the shadow still prevailed, and so definitely was the thick grey water separated from the clear dark water that no mixing appeared to be taking place. We steamed across the united rivers, which form the Nile of Egypt, and tied up to the bank at Omdurman alongside three of the gunboats which had played so important a part in the "river war." Near by stood the works where many an old steamer, which most engineers would have broken up for scrap iron-one at all events dating from Gordon's days-has been miraculously patched up and made to work again.

There was much to be done at Omdurman, and the dust and heat as well as the extent of the place by no means facilitated matters. The town is a most bewildering place. It is built on a fairly flat piece of bare desert about six miles long by an average of two miles wide. This piece of desert is a mass of low mud houses surrounded by compounds and separated by high walls. A few broad straight roads, which are mere sand, and innumerable narrow winding alleys, intersect the collection of huts and compounds, while here and there is 
a yawning pit, or an acre or so of broken-down houses, such as those in the Baggara quarter, which is now but

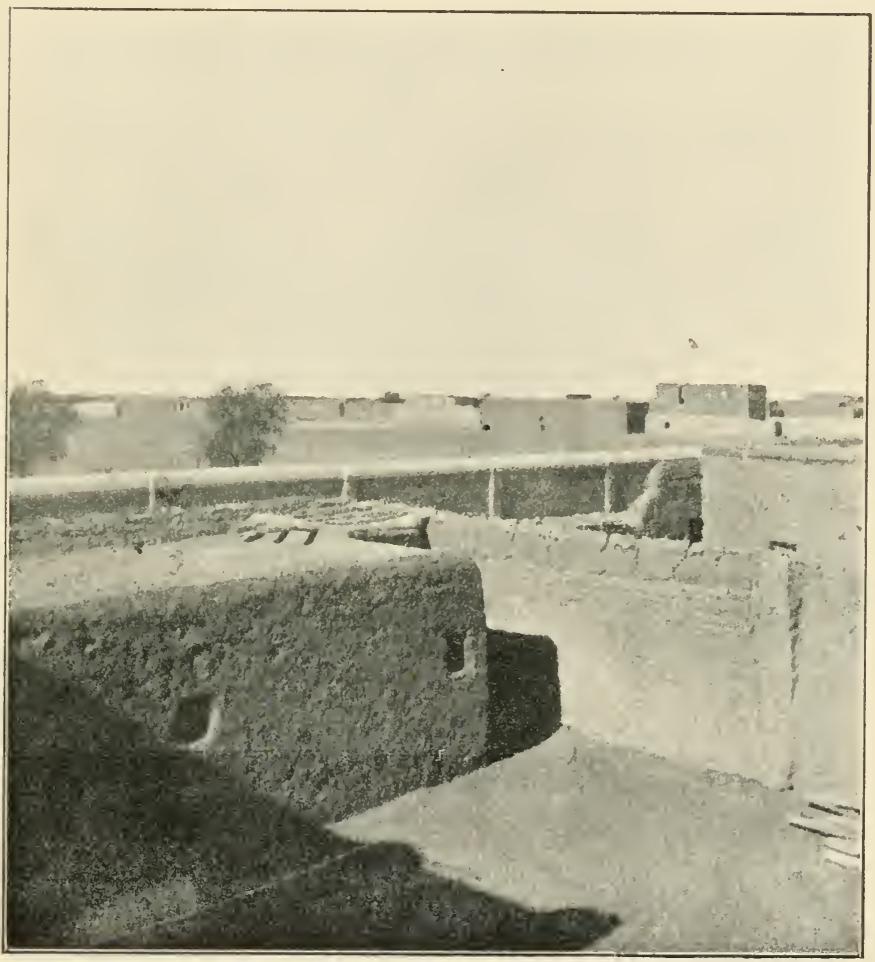

THE GREAT SQUARE IN OMUURMAN WITH THE KHALIFA'S HOUSE (WITH FLAGSTAFF).

a heap of mud. Although the place itself has a peculiar fascination, perhaps on account of its history and the many unlooked-for secrets these numerous walls may 
even now be hiding, there is not much of interest to see in Omdurman. The houses are mostly built on the same plan-four mud walls with a flat roof made of rafters covered with straw or matting, a verandah in front, and sand for the floor. The few which have two stories were formerly occupied by the Khalifa and his chiefs. The Khalifa's own house stands at the corner of an immense square some 600 yards long. Outside the house in the square one can see the remains of what was once a brick platform, from which the Khalifa used to preach to his thousands of fanatical followers packed in the great square. There on the last day of August, 1898, he held his last review, inciting the assembled hosts in a vigorous harangue to fall upon the invading army of British and Egyptians, to drive them into the river and annihilate them, and there the dense mass of misguided savages clad in their patched jibbehs shook their spears and became mad for the blood of the accursed infidels.

In 1900 in the same square a few orderly squads of Soudanese, dressed in neat khaki uniforms, might be seen industriously drilling to words of command given by a sergeant as black as themselves, with neither an Englishman nor an Egyptian present. Yet most of these Soudanese were the same men who had thirsted for and 
spilt our blood such a short time before. That they were no less eager to fight one could tell by the fierce energy of their drill, but above them, near their former master's house, floated two flags side by side-the Union Jack and the Crescent and Star, and around them, working in the houses so lately occupied by their ignorant and brutal

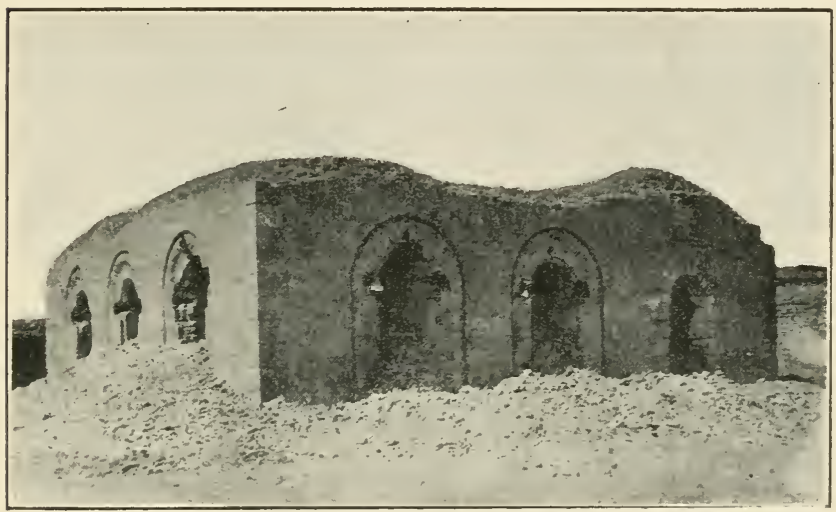

THE RUINS OF THE MAHDI'S TOMB.

chiefs, were a few British officers in their shirt sleeves administering the Soudan. Just outside the great square is a small enclosure surrounded by high walls, and in this may be seen a great heap of bricks with a square of arches round it--all that is left of the Mahdi's tomb, for ten years the most sacred and revered object in the Soudan. Leading out of this enclosure is a compound 
with a small mud house, the English Officers' Club, and here every evening the Soudanese may catch a glimpse of the members playing tennis or racquets. One of the most interesting places in Omdurman, although now in ruins and difficult to find, is the "Saier," the awful prison in which Charles Neufeld and so many other victims of the Khalifa spent years in torture. Slatin Pasha writes thus of the horrors of this place:- "A gate, strongly guarded day and night by armed blacks, gives access to an inner court, in which several mud and stone huts have been erected. During the day-time, the unhappy prisoners, most of them heavily chained and manacled, lie about in the shade of the buildings. .... At night the wretched creatures are driven like sheep into the stone huts, which are not provided with windows. .... It is a painful sight to see scores of half-suffocated individuals pouring out of these dens, bathed in perspiration, and utterly exhausted by the turmoil of the long and sleepless night."

The walls round this awful place are now broken and crumbling, and only portions of the huts remain. But enough can be scen to make it almost impossible of belief that any of the crowd who were forced into these dens could have lived through one night. That many succumbed we know. Outside the huts in the 
small compound could be seen the remains of three or four brick platforms on which the most favoured prisoners were allowed to rest at night.

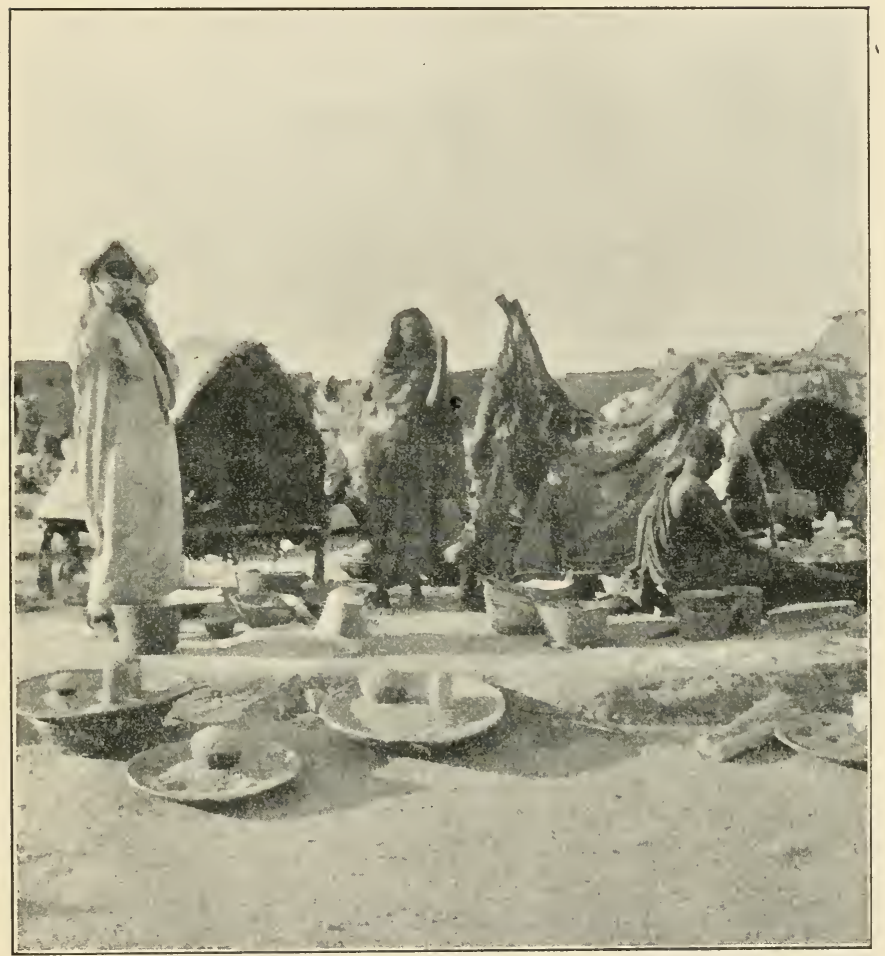

IN THE MARKET AT OMDURMAN.

To turn to pleasanter things. Of the birds of Omdurman itself there is little to say. There is not a tree near the town, nor is there any vegetation. Consequently there 
is little else but carrion on which a bird could feed. Kites and Egyptian vultures, || both excellent scavengers, are the most conspicuous birds. And all over the town are homely house sparrows, 9 a little smaller and more brightly coloured than our familiar birds, but every whit as cheeky and pushful. Down by the river one may often see a striking black and white kingfisher, ${ }^{*}$ hover. ing over the shallow water, and every now and again dropping down to the surface like a stone. If you watch carefully you will notice that this graceful action is repeated many times before the bird makes a successful plunge and rises with a fish.

Across the river, on a sandbank, a few pelicans, $\dagger \dagger$ some graceful egrets and herons, $\ddagger$ and other wading birds may be distinguished.

When once we got into the swing of things and began to learn our way through some of the mazes of the town, preparations for our journey up the White Nile did not take long. Time being precious I determined to spend as little as possible in travelling, but to work thoroughly a small tract of country from Omdurman

II Neophron percnopterus, Linn.

- Passer rufidorsalis, Brehm.

** Ceryle rudis, Linn.

+† Pelicanus onocrotalus, Linn.

++ Herodias ralloides, Scop; Herodias garzetta, Linn.; Ardea purpurea, Linn. 
south along the White Nile. With this object in view we decided to travel entirely by land, as being a more thorough method of exploring the country, although much slower and more fatiguing than travelling by boat. Our task in Omdurman was to obtain permits and servants, and animals to carry our baggage and ourselves. At first we tried to buy camels, and several Arab sheikhs were induced to make a parade of their beasts before us. Feeling sure, however, that such camels as were shown us would become the prey of dogs and vultures after a day's march, we waived their owners politely away. At this deadlock I learnt most opportunely that His Excellency the Sirdar, Sir Reginald Wingate, through the agency of Bimbashi F. G. Newall, of the Intelligence Department at Omdurman, had most kindly already hired baggage camels for me from the sheikh who contracts to supply the Government. This difficulty being thus pleasantly overcome we turned our attention to procuring our own mounts. Good horses and saddles were difficult to obtain, and to feed horses in such a dry season would have been a difficult matter. Riding-camels were expensive, and a doubtful luxury. We, therefore, fell back upon donkeys. But the donkey of the Soudan is a miserable little beast compared to that of Egypt, and although our animals, bought after 
a wearisome amount of bargaining and trials, carried us fairly successfully, we often wished for better mounts. We made a great mistake in using the wide wooden native saddles, which even with the aid of pads and a sheepskin became exceedingly uncomfortable at the end of a long day's march. Quite the mount for our journey would have been a bicycle. The desert tracks, at all events as far south as we travelled, are quite hard and smooth enough to make bicycling possible and often enjoyable.

A permit to travel as far south as we cared to go on the east bank of the White Nile was granted us, but we were prohibited on account of the unsettled state of the country from journeying on the west bank at all. This somewhat altered my plans as I had hoped to be able to make several excursions into Kordofan from the west bank.

Licenses to carry arms and to shoot were also necessary. By licensing each gun, rifle, or revolver, instead of the user, the authorities make a distinct gain for the Revenue. Some very fair game laws have also been drawn up for the Soudan. No one is allowed to kill the zebra or the ostrich. A special license authorises the holder to kill a very limited number of adult male buffalo, elephant, giraffe, hippopotamus, and rhino- 
ceros, and for each animal killed, a special fee has to be paid. A less expensive license allows one to kill antelope, gazelle, and warthog. All other animals and birds may be shot by the holder of an ordinary gun license. These regulations might well be revised and made still more useful, and no doubt Capt. Stanley S. Flower, who has lately been appointed Director of the Soudan Wild Animal Department, will see to it that better protection is afforded to many scarce animals, such as giraffes and some of the rarer antelopes.*

Having obtained all the necessary permits as well as baggage and riding animals, our next task was to engage servants. We eventually gathered together a motley and somewhat amusing crowd. The chief of these-one Hassan Mahomet El Shami, an Egyptian-we brought from Cairo, and he proved in every way an excellent interpreter and hard-working headman and servant. Mustapha, who hailed from Berber, was a cook as well as a lazy and perfidious rascal. Mahomet-an old

* The Soudan game laws have been considerably altered since this was written, and many more animals and birds are now protected throughout the Soudan. As the regulations are somewhat compli. cated, I cannot refer to them here bejond expressing an appreciation of the wisdom with which they have been drawn up. Those interested in this question should obtain a copy of a pamphlet issued by the authority of the Soudan Gorernment, entitled "Notes for Travellers and Sportsmen in the Soudan," in which the game laws are set forth. 
kingly-looking Turk, whose ankles were callous through the shackles of the Khalifa-was "sais" to the donkeys. He was a fine figure, and generally rode in front of our caravan, ordering the natives out of the path, or commanding them to come and show the way for a mile or two, all in a most dignified manner. But when it

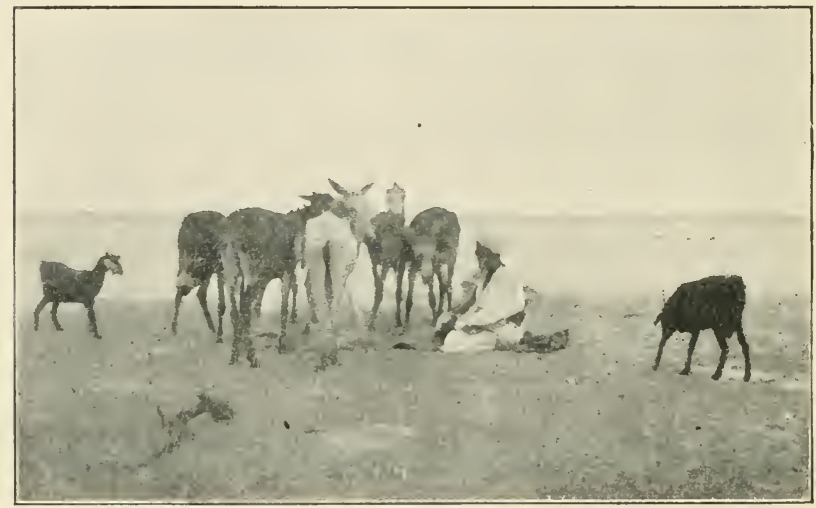

MAHOMET AT WORK.

came to work in camp his one idea was to sit on his haunches and smoke, and to obtain the services of the nearest wandering boy to wait upon him and his donkeys. The natives feared him much, and generally obeyed him without a murmur, but all our hard sayings and harder doings failed to make much permanent improvement in his habits. 
We had great expectations of Mirsal, an old Soudanese soldier, who was to act as a gun-bearer. When I engaged him he went through a most charming pantomime. Gripping his right arm with his left hand, he swore by the Prophet's beard that so long as there was strength in that arm he was my most faithful servant. A few days later, when on the march, we sent him over to a village on the other side of the river with money to buy food and tobacco. We never saw him again, nor could policemen mounted on camels find him. But maybe we misjudged him. The strength may have forsaken his arm. Our camel men were from Dongola. They were a lively, irresponsible crew, requiring much physical persuasion. On the whole, we were not greatly impressed by the reliability of the natives of the Soudan, as far as concerns either work or honesty.

Our final plan was to travel up the river quickly, and to return slowly. While marching up the river we, of course, should have no time for collecting or preserving, but we should be able to make notes of the birds and the country, and thus obtain a knowledge of the ground which would greatly assist us on our return in deciding where to make collecting camps, and how long to stay at each.

With much kind help from many in authority at 
Omdurman all our preparations were at last complete, and on the afternoon of March 20th, we sent our men, animals, and baggage across the White Nile to the Khartoum, or east, bank. Joining them early the next morning we found to our great relief that there were no deserters, and, moreover, that all disputes as to which box or package should be carried on which camel were settled, and all were ready to start. The apportionment of loads and the loading up at the start are always difficulties, and never before had we experienced so little trouble.

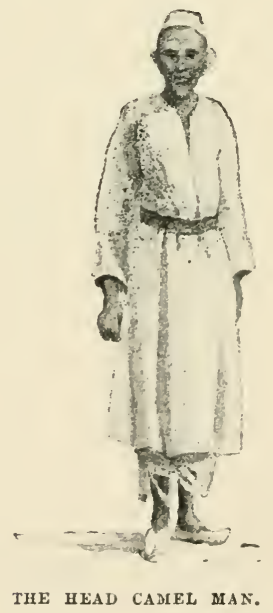

Diaun from a Photograph. 
CHAPTER II.

\section{THE RIVER-ESSENTIAL ALIKE TO MIAN, BEAST AND BIRD.}

T $\mathrm{T}$ is remarkable how regular a stride and how even a pace the baggage camel will keep up hour after hour. Two and a half miles an hour is his pace, and twenty miles is for him a good day's journey. As the camels carried our food, tents, beds, and indeed all our baggage, we had to arrange our day's march according to theirs, our procedure being generally as follows:-Rising just before the sun (about 5 o'clock) we breakfasted, struck tents, packed up and got away about seven, marched for five hours, then rested during the heat of the day, and marched again for some two or three hours in the afternoon, getting into camp as the sun was going down, about 6.30. We travelled thus to a point some ten miles south of a town named Kawa, on the east bank 


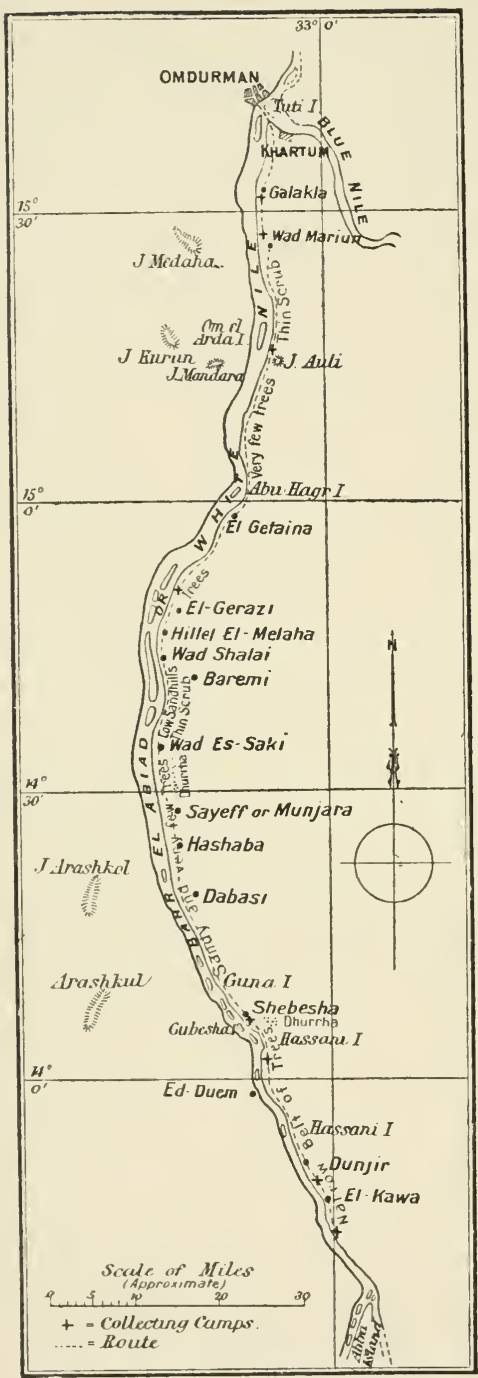

Sketch Map, shouting Route and Collecting Camps. of the White Nile, about 150 miles south of Khartoum, and there we stopped and made our first collecting camp.

A reference to the accompanying sketch map will give an idea of our route. $\mathrm{We}$ marched as a rule close along the river, which was in many ways more convenient and pleasant than the desert track. At high Nile the route by the river is impossible, as much of the land is then flooded, and long detours here and there are necessary to avoid the "Khors" (equivalent to the South African "dongas "), 
some of which during the rains are often impassable torrents, whereas in the hot season they are merely dry watercourses. Often we rode for miles along the narrow strip of short grass which in places grows by the river, but now and again this pleasant going gave way to soft sand, which was trying for the donkeys, and, if a heavy wind was blowing, disagreeable for us. But more annoying still, and more frequent, were the wide stretches of mud, which, covered by the river during its flood, were now hard, caked and cracked in every direction by the powerful sun. So large and deep were these cracks, and so numerous, that our donkeys continually got their legs into them, the result often being a sudden collapse of the beast and the discomfiture of the rider, while sometimes a donkey's legs became so firmly fixed in a crack that it required our united efforts to lift him out again. After due experience of this method of travelling we avoided the wider stretches of mud by turning off into the desert track, which although hot and dusty, was at all events firm.

One does not need to travel far up the White Nile in the dry season to be impressed by the fact that the life of every man, beast and bird in the country is entirely dependent upon the river. Beasts such as 
camels and even goats can be gradually trained to exist without water for as long as two or three days, but man cannot live long in this burning country without the lifegiving water, as many a poor wretch has proved, while birds are even more dependent upon it. There is no dew, and save for a small well here and there at long intervals, water can only be had at the river. Man, or rather woman for him, has to come there to get his water, and thither he has to drive his camels, cattle and goats, often from long distances, to drink.

To the river every morning and evening, as regular as clockwork, flock after flock of sand-grouse and pigeons come down to drink. All day long small birds are passing to and from the trees and bushes to the river's edge, while at dawn or in the evening, wild beasts of many kinds come from their haunts on the same errand. But man is dependent apon the river not only for the water he drinks, but largely also for his food. It is true that much "dhura," the corn of the country, is grown during the rainy season out of reach of the Nile even at its greatest height, but by far the larger part and the richer part of the cultivatable land is the mud which so troubled our donkeys, and this mud is entirely dependent upon the flooding of the river to render it fit for agriculture. The same may be said of the 
islands in the river, which are covered at high Nile, and afterwards prove of the utmost value for cultivation. So rich is the land on these islands that even the lazy Soudanese find it worth their while further to utilise the river by raising the water with the "shadoof," and so continue cultivation during the dry season. At the time of our journey these islands were almost the only green spots in a wilderness of brown and sun-scorched land. At long intervals only, did one or two "shadoofs" keep green some small patches of onions, water melons or beans on the mainland.

As a highway, the river is extremely valuable. Sailing boats of various kinds-gyassas, feluccas, nuggars and even dahabiehs-are continually travelling up and down laden with corn and other produce, while rafts of all sizes are numerous. The timber forming a raft is generally of the "sont" tree, a species of acacia, and is cut by a few natives who join together for the purpose. When the wood is cut and floated, and the raft completed, they thrust it out into the river, and are then entirely at the mercy of the current, which flows some one or two miles an hour in the dry season. These men make their home on the raft, protecting themselves from the sun by improvising awnings of the cloths which they wrap round their bodies at night. Eventually the 
current carries them to Omdurman, where they get a good price for the wood as fuel, which is exceedingly scarce near the town.

Besides the sailing boats and rafts, steamers ply up and down the White Nile at least three times a month, to carry passengers, and to take rations and other things

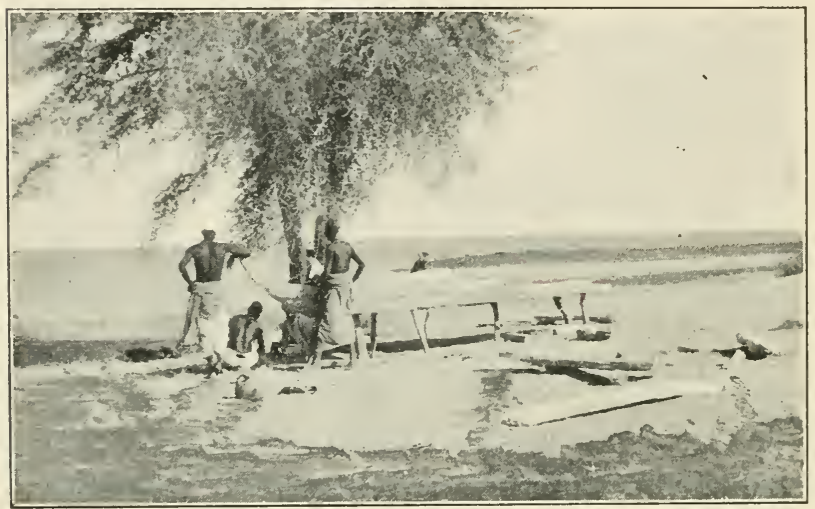

BOAT-BUILDING ON THE WHITE NILE.

to the troops stationed at various points. Now that a channel has been cut through the Sudd on the upper White Nile the river is navigable for 1000 miles south of Khartoum. From Cairo to Khartoum is some 1500 miles by river. Some day when channels have been cut through the cataracts, by no means a very remote probability, it will be possible to steam 2500 miles up this wonderful river at all times of the year. 
The wild life in the river and along its banks was a continual source of pleasure to us as we rode along. Hippopotami were rarely seen, but now and again an enormous black head would show above the water for a few moments, and sometimes a long black ridge in the middle of the river would denote where a hippo was resting on some sandbank barely covered by the water. We often saw gigantic footprints on the bank, where one of them had come out of the water to feed, and at night the natives light fires at intervals along the river side to keep the great beasts in the water, for a patch of beans is little to boast about after even one hippopotamus has been browsing on it.

Much further south than we travelled the hippo is exceedingly common, and notwithstanding the restrictions, many must be killed if one may judge by the universal use of the "korbag," a whip which is made out of its hide. It is curious how this whip, which, by the way, we found very usefull for both man and beast, is employed under various names (such as "sjambok" in the south) all over Africa. Crocodiles were common and were often to be seen, sometimes three or four togetlier, lying asleep on the bank, facing the breeze with their mouths wide open. Once we saw two calves standing unprotected at the water's edge, and just as we passed, 
the ugly head of a crocodile appeared within ten yards of them, but it slowly drew back on seeing us. As a rule the natives make a ring of thorn bushes in the river where they water their goats and cattle to protect them from the crocodiles. But they seem to have no fear of the reptiles for themselves. They wade out into the river to fetch water; if a boat sticks on a sandbank the crew jump out without hesitation; and, more remarkable still, fishermen may often be seen standing motionless up to their shoulders in the water while fishing with nets. The natives are very fond of the flesh of the crocodile, and once when I had shot, but failed to kill, one of the reptiles, our camel men threw off their clothes and rushed into the river in the hope of "tailing" it. It is true that the men were hungry at the time, having squandered their money upon "merissa" or "boozer," and having had little to eat for some time, with the exception of a large fishing eagle, which they had consumed with avidity some hour or two after it had been shot. A specimen of this eagle, the vociferous sea-eagle, ${ }^{*}$ may be seen at the Zoological Gardens in London. With its white hood it is a conspicuous object, and a fine looking bird when

* Haliaëtus vocifer, Daud. 
perched upon some tree or on some snag in the river, but near at hand it is dirty and disappointing looking, and to my taste decidedly unappetising.

Other birds abounded in the river and on its banks. Nile geese $\nmid$ were numerous, but very wary. The white man shoots at them with every sort of firearm at every

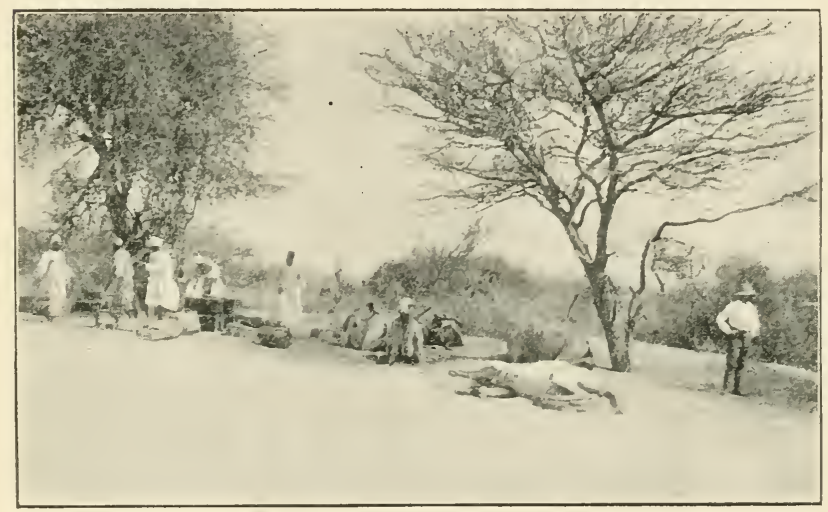

$\triangle$ MIDDAT HALT.

sort of range, for their flesh is good, and the natives, with shouts and sticks and stones worry them out of their bean crops. Another much handsomer and larger goose, the spur-winged goose, $\ddagger$ was rarer, and so cautious that we were never able to shoot a specimen. Cranes, storks, ibises, and herons of various kinds were generally

$\dagger$ Chenalopex agyptiacus, Briss. $\quad \ddagger$ Plectropterus rïppelli, Sclat. 
in sight wading in shallow water or stalking about on the short grass by the river. We sometimes passed within a few yards of a group of crowned cranes, $\S$ with their rich colouring of black, white, and chestnut, and their curious tufts of golden grass-like feathers, and at one camp a confiding old bird used regularly to roost on the top of a tree near our tents until he was added to our collection. The sacred ibis, $\|$ celebrated by having been much mummified, and by its many portraits upon the tombs and temples of ancient Egypt, was most confiding. This bird only visits Egypt during the period of inundation, and consequently very few travellers in that country see it, the buff-backed heron being made to do duty for it by the tourists' dragoman. However, the real thing is totally unlike the substitute. Its jet black head and neck, which are bare of any feathers, and its black legs, serve to accentuate the pure white plumage of its body, while its wings are edged with black like a mourning envelope, and from each shoulder droop green-black feathery plumes. When flying towards one the bird seems to be streaked with blood, for the wing-bones are bare of feathers on the under side, and the skin which covers them is of a rich 
vermilion colour. At intervals along the river were beds of shell fish (Aetheria) like oysters. The Nile fell so low in 1900 that a great many of these "oysters" were left high and dry, and were consequently decomposing. Yet numbers of wading birds frequented the beds, and amongst them none were more conspicuois than the Marabou storks, $T$ the African representative of the adjutant of India. Not only were they conspicuous by their size and form, but their dull-looking plumage, their bare reddish-yellow heads, and their enormous dirty bills, gave them a most revolting appearance. They are carrion feeders, and seeing them smash open the oyster shells with their massive and powerful bills one could well understand how it was that after the battle of Om Debreikat many a man, well accustomed to gruesome spectacles, shuddered at the sight of corpses mutilated by these birds. Another interesting member of the stork family which frequented the "oyster" beds was a sombre coloured bird with a thick whitish bill, the mandibles of which are so grooved near their tips, that an open slit is left when the bill is closed, a peculiarity which has given the bird the name of openbill.** Of the many other birds frequenting the river

- Leptoptilus crumeniferus, Cuv.

** Anastomus lamelligerus, Temm. 
the pelicanst† were, perhaps, the most striking. One evening as we urged our mounts over the brow of a small sandhill we came suddenly in sight of a great flock of these birds in the shallow water at the river's edge. Some were dozing, others were preening their rose-white plumage, others were dabbling their clumsy-looking bills in the water and washing their yellow pouches, while over the whole flock the setting sun threw a delicate rosy hue.

For so large and heavy a bird the flight of the pelican struck me as being peculiarly graceful. A few powerful flaps are given as the bird rises slowly off the water, then the wings are outstretched and it skims straight and swiftly along within a foot of the surface for some hundred yards, then curving slightly upwards, it flaps its wings again and is prepared for another long floating flight.

Before leaving the river and its attractive birds, the black-headed plover, $\ddagger$ or courser, a bird somewhat smaller than the golden plover, deserves mention if only on account of the interesting and historical habits accredited to it. There can be little doubt that this bird is the " $\tau \rho \circ \chi$ i os " of Herodotus, who ascribed

†† Felecanus onocrotalus, Linn. $\quad++$ Pluvianus agyptius, Linn. 
to it the habit of attending crocodiles, and of feeding in their open mouths. At least two naturalists in modern times have actually observed the bird thus act. Some ornithologists, however, are disinclined to believe that it does really enter the crocodile's mouth, and suggest that when a crocodile is lying with its mouth wide open, a bird running about on the sand behind the mouth would appear at a little distance to be actually between the reptile's jaws. However this may be it seems a pity now to discredit a habit which has made the "crocodile bird" a celebrity for so long a time. I am sorry to be unable to give any evidence on the subject. The bird was very common along the banks of the White Nile, and we much admired its rapid and graceful actions and its beautiful plumage of delicate blue-grey marked with white and black, but we never saw it near enough to a crocodile even to suspect it of engaging in the laborious and risky task of picking the reptile's numerous and merciless teeth. 
CHAPTER III.

THE COUNTRY AND THE PEOPLE.

$\mathrm{M}$

Y last chapter treated of the river with the stretches of grass and mud bordering upon it. Fringing the mud and stretching inland, for half a mile or so in most parts, but in some places for two miles, is a belt of wooded country. The trees composing this belt are chiefly of the acacia family, many of them being of a gum-bearing species, and under and around them is a thick undergrowth of mimosæ, cacti, and other bushes. At the time of our visit the trees and shrubs, with few exceptions, were practically bare of leaves, so that, had not the trees been thick with branches there would have been but little cover.

Vegetation seemed entirely at a standstill, and the hot season might well be termed the winter in this 
district, especially as the general breeding season for the birds was over. Of the 141 species of birds which we identified only four or five appeared to be nesting. A small lark, ${ }^{*}$ which lived on the ground and continually sought the shade of some bush, made the neatest of little nests in the dry mud by the river. The nest was a small shallow "cup" composed of dry grass and a few bits of cotton, while round the cup was a compact and neatlyarranged layer of particles of mud. Only one egg was laid. Two species of doves were also nesting. The nest and eggs of one of them were much like those of our Turtle Dove. The other, $\S$ which was a pretty little longtailed bird, buiit an exceedingly slender nest even for a dove. It was round in shape and only $3 \frac{1}{2}$ inches in diameter. The two eggs were of a dark creamy colour. The young were most quaint objects lightly covered with whitish down. The smallest|| of the many shrikes which we found was the only one breeding. I watched a pair at work on their neat chaffinch-like nest, which was placed in a fork of a horizontal bough some 30 feet up an acacia. The birds brought material at intervals of a minute or less during the considerable time I watched them. They invariably sat in the nest and

* Pyrrhulauda otoleuca (Temm.) $\S$ Oena capensis (Linn.)
‡ Turtur ambiguus, Boc. \| Nilaus afer (Lath.) 
turned rapidly round in it as they built in each mouthful of stuff which they brought. The outside of the nest they plastered with cobwebs.

As the dry season affects the foliage of the trees, so does the river influence their growth. When the river is at its greatest height many of the trees on its flat banks are flooded half-way up their trunks. These trees are numerous and of a fair size, but they quickly decrease in number and height the further they grow from the water, and are soon replaced by tall bushes. The bushes struggle onwards, becoming gradually smaller and getting thinner, until they finally cease for the want of water. Beyond, as far as the eye can see, stretches a flat desert with here and there a thorny leafless bush or a clump of withered grass, while near and far the deceitful mirage sets forth its enticing pools and ponds and lakes-a mock vegetation and a mock water in a merciless fiery land. This desert is formed for the most part of a grey and gritty cotton-soil, but in a few places it is of a true yellow sand.

At several points in our route there were "stations," where a large amount of wood is cut and collected for the use of the steamers. Notwithstanding the scarcity of timber near Khartoum, and the fact that no other fuel is available, the gangs of natives employed to chop 
this wood were not then under sufficient supervision. The consequence was that much wood had been wasted and many fine trees ruthlessly maimed. We often passed a mile or two of stumps four or five feet high left in the ground, and so many of the best trees had been mercilessly lopped by the careless and ignorant natives, that near these wood stations it was often impossible to find shade for our tents. I was assured, however, at Omdurman, that the method of cutting the timber would shortly be improved.

The mimosa bushes, which form the dense undergrowth, are thickly covered with thorns of three to five inches in length, exceedingly sharp and strong, and of a dazzling white as though they were enamelled. When our stock of pins became exhausted we found these thorns very useful in packing bird skins, but they made the country difficult to "negotiate." One was driven through my boot into the foot, another pierced the leg of one of my companions, and a third completely lamed a donkey for a month. The acacia trees, too, are plentifully provided with smaller but no less annoying thorns, and there appeared to be but two varieties of bushes without them.

Perhaps I have not drawn a very enchanting picture of the country it was our good fortune to work in, yet, 
notwithstanding its undoubtedly monotonous character and the lack of the pleasing colours and sun effects of Egypt, there is a peculiar fascination about this country near Khartoum. Its very extent and barrenness are a charm and confer an exalted idea of freedom on the

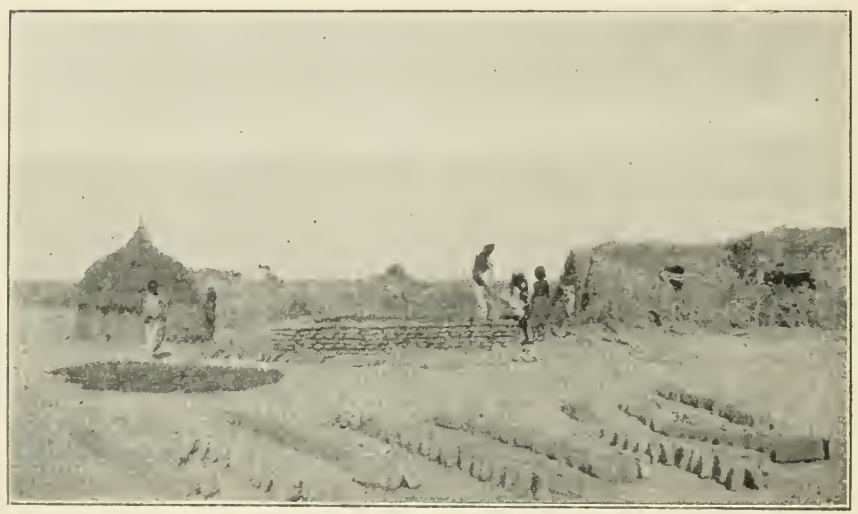

DUILDING A SQUARE BRICK HUT.

The bricks in the foreground are baling in the sun.

traveller, while the scarcity of cover causes the naturalist to search through what little there is with an exaggerated delight and keenness.

The natives of these parts rarely lived under the trees. Every village of any importance was situated on the bare desert with no protection from the burning sun or scorching wind. In the vicinity of the villages there 
were always to be found large patches of ground used as cemeteries. The graves were very slight mounds, having a stone, or a stick with a piece of white cloth tied to it, planted at either end, while a number of broken pitchers were placed bottom upwards here and there in the cemeters. The huts composing the larger villages were usually round in shape with conical straw roofs, the walls being built with bricks, which are burnt only by the heat of the sun. Some were square with flat roofs built in the same way as the majority of those in Omdurman, while a few had a rough verandah in front. All along our route, however, there was a great number of people living in very small huts which could be "struck" and moved about almost as easily as tents. These huts varied in shape and in the material with which they were constructed. Some were round with conical roofs and were entirely made of "clhura" straw, while a few were dome-shaped. The majority, however, were oblong, measuring about 6 feet broad and 7 or 8 feet long. These were not more than 5 feet high, and had flat roofs usually made of straw or matting, but sometimes of fodder, so that more than once a native sold us lialf his roof as food for our camels. Straw, cane matting, or cloth was used indiscriminately for the walls. The rough cloth used for this purpose is 
made of a mixture of goats' hair and sheep's wool, which is spun by the women on to a rough spindle in the same way that they spin cotton. A primitive loom is made on the ground with poles held in position by

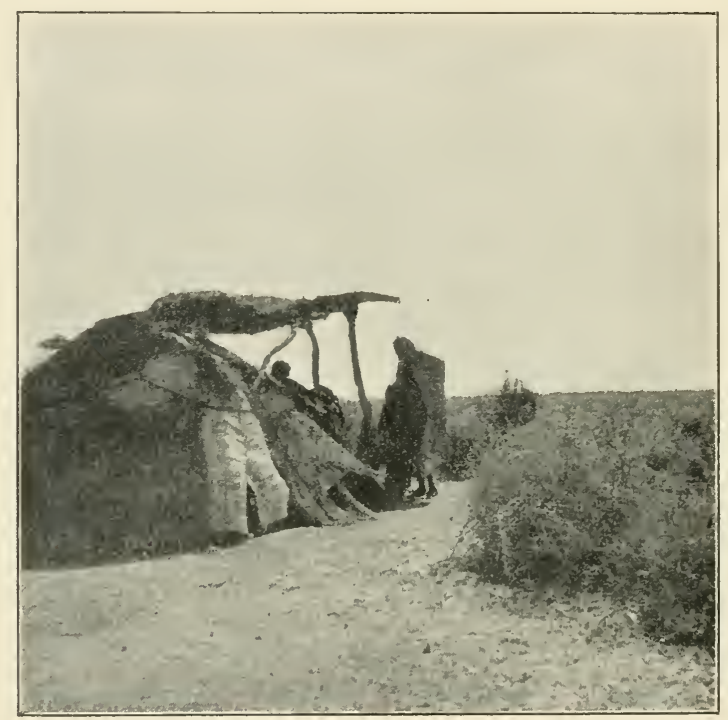

A DOME-SHAPED HUT WITH A "VERANDAH."

The hut is made of matting and cloth.

pegs driven into the sand, and the women while weaving squat down under a temporary sun-shelter. These movable dwellings were sometimes placed under trees, but generally in the open, and there were seldom more than six or eight together. The natives inhabiting 
them were very shy, and twice when we pitched our tents near an encampment the people were soon busy rolling up the matting and cloth forming the walls of the huts, and in a few hours disappeared, carrying away their roofs by the four corner poles, their rolled-up walls, and all their goods and chattels. When asked why they moved away from us they gave no reason beyond remarking that they objected to our tents being near them.

In two or three places we found natives living in a much rougher sort of hut, built under very thick bushes which had been cut out in the middle and thickened on the outside, thus forming natural "Zareebas."

The reason for such diversity in dwellings lies in the mixed character of the population of this stretch of country. Arabs and blacks of many tribes inhabit it, and although rather thinly populated, the people were so evenly distributed along our route that we were scarcely ever out of sight of a native. At the time of cur visit the men were enjoying idleness, but the women were always hard at work carrying water or grinding corn. The corn is placed upon a wide and heavy stone and is then ground with a smaller stone, which is rubbed and rolled backwards and forwards. The stones wear away rapidly, and a family must actually consume a 
goodly number in a lifetime. The boys are also kept busy shepherding the goats and sheep, which are in thousands all over the country. These animals are very rarely slaughtered and are kept merely for their milk. In the wet season, of course, conditions are entirely

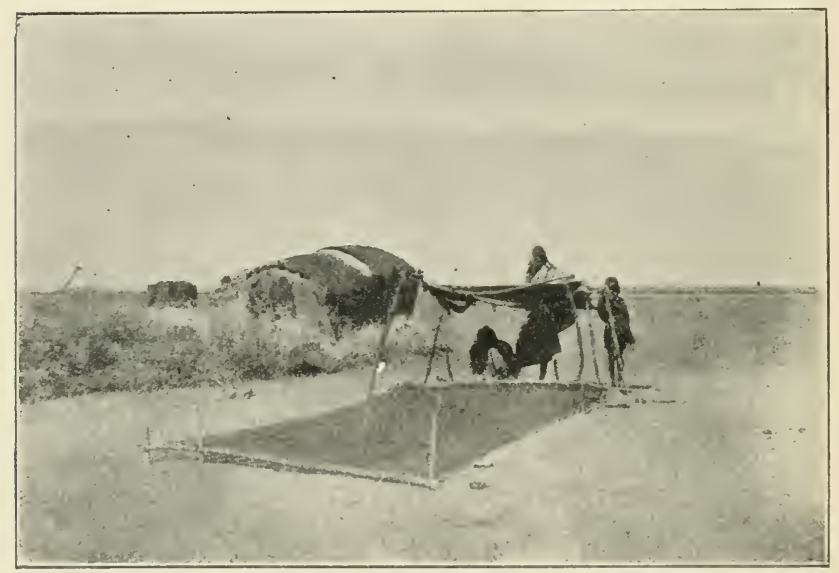

A NATIVE LOOM.

changed, and the men are busily employed growing "dhura," maize, cotton and other produce. At the end of the dry season food becomes so scarce that the goats are fed upon the roots of the grass, the grass being hoed up, and the roots beaten soft with short wooden clubs.

Near the large villages we found the natives 
decidedly independent and difficult to get on with. In the smaller villages and isolated communities the dress, or rather the greater want of dress, at once showed the people to be of a more unsophisticated nature. They greeted us with many salaams and much kissing of hands, and were more willing to give us such supplies as they could, but very little work could be got out of them.

At every cainp we harangued the "Sheikh" of the nearest village and asked him to procure us animals for our collection, but we stipulated that they should be brought in alive and uninjured. We offered varying rewards, but at only one camp did the natives show any interest or take any trouble to earn the reward. At this camp, near a rocky hill named Gebel Auli, a number of bats and some rather rare hedgehogs, caught in the caverns on the hill, were brought to us. The bats were captured by a boy who appeared with his shirt bulging out and held up to his neck. Out of the shirt were extricated, amidst considerable amusement and excitement, half-a-dozen live bats with long and very sharp teeth, which were more than once used with great effect. The bats were swarming in the cracks and caverns of Gebel Auli, and their squeaking could be heard at a considerable distance. The natives poked 
long sticks into the cracks and out flew the bats, which were knocked down with cloths. The hedgehogs which were brought to us from this same hill were exceedingly pretty little beasts with dark spines and white hair. On them we discovered some elegant yellow fleas, which

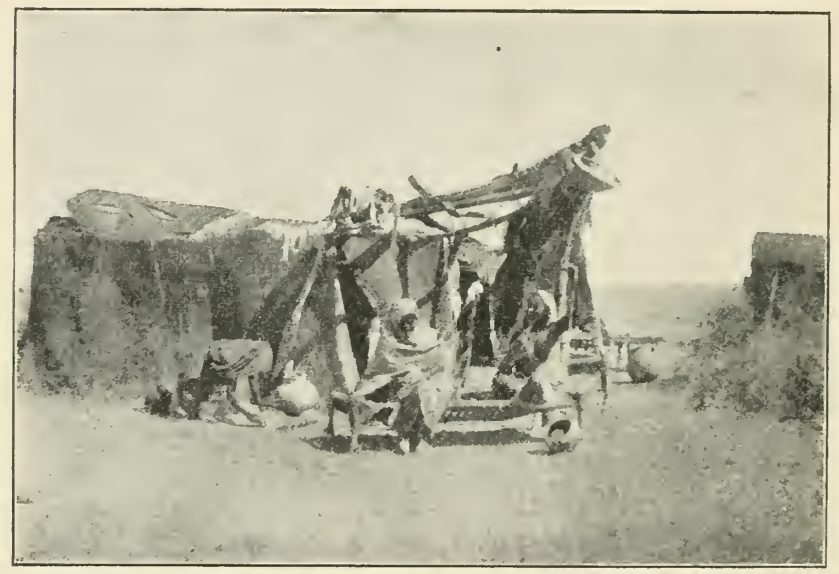

A MOVABLE HUT MADE OF MATTING.

The voman on the left is grinding corn, while the two seated on the "angarib," or native bedstead, are spinning,

I gave to the Hon. N. Charles Rothschild, who collects these parasites. He proclaims them a new species, and has done me the honour of naming them Pulex Witherbii!

In general, however, the offer of a reward for animals would produce great keenness among the natives for cnly a day or so. They would bring in any number 
of the common rats of the country and, although we stipulated for live animals, every bone, skull, or bit of skin that could be found would be brought in the hope of reward. But when they found that we needed no more of the rats that swarmed in their huts, these very lazy natives returned to their normal occupation of sleeping and eating and refused to hunt any further. This seems extraordinary, because luxuries to a certain extent can now be bought for money in the markets of all the larger villages through which we passed.

In the days of the Khalifa it was rather a disadvantage for a man to become prosperous. The tyrant would soon hear of it, swoop down upon him and carry off his flocks and corn. As several natives said to us when we asked them why they refused the money we offered for goats' milk: "The Khalifa never took the milk, he always took the goats unless they were driven away and hidden. Now you come and only want the milk and offer to pay for that!" No doubt they think the English fools.

Although singularly uninquisitive the natives provided one of the trials of collecting by their ubiquity. One could never be sure on shooting at a bird whether a concealed native would not rise from behind a bush in the line of fire at the moment. 
We never actually shot anyone, however, although there were many narrow shaves. The traps which we set for mammals, although carefully concealed, seldom brought us profit. Goats tramped over them, natives stole them, presumably for the copper wire of which they were made, and dogs dragged them away for the meat with which they were baited.

These dogs, as is usual in Africa and the East, are never fed, and consequently become very bold and expert thieves. I had the misfortune to be ill in our first camp, and the dogs used to creep into my tent at night and drink the milk at my bedside.

Another visitor, but a pleasing one, appeared in the daytime. This was a little bird-the Lesser Whitethroat-a summer visitor to England, and exceedingly numerous during our winter and spring on the White Nile. The Whitethroat came to my tent for water, a bucket of which was kept near my bed. On the very first day of my illness this bird found out the water and came into the tent, perching on the bed or my arm. It stayed there most of the day, and whenever I splashed my hand in the water it would hop down my arm and suck the drops of water from my finger tips. 
The bird was always thirsty, and although the river was quite near it seemed to prefer to drink in this way, and so I was amused by this delightful little bird all through the heat of the day. I missed it much on moving from this camp.

The extreme dry heat of the country affects the birds perhaps more than other animals. All the land birds, large and small, almost always kept their mouths open as though gasping in the heat. Yet they sing, some of them as beautifully as our songsters, and seem as happy as birds usually are. We used to take advantage of their propensity to drink as a means to entice them within range of the camera. A tin of water was placed in the sand at a few yards distance from the camera, which was kept focussed, and ready for action whenever a bird came to drink. In this way many interesting photographs were apparently secured, but alas, on development, all my "photographs" proved complete failures. Messrs. Dallmeyer had carefully fitted up for me one of Messrs. Watson \& Sons' "Gambier Bolton" cameras with telephoto lenses. The camera proved strong enough to resist the heat and the camels, and would no doubt have worked very well had I taken plates and risked the great chance of their being broken. I chose, however, to take films, which became seriously 
affected by the great heat, and were, moreover, defective in the making as regards the emulsion. For this ruinous defect the maker deserves to be named. Such a defect could, of course, be guarded against by testing each batch of films before starting, but the fogging due to the heat cannot be avoided. I think it wise to mention this because, although I am well aware that films are often perfectly successful in very hot climates, they are as often not, and the successes are well advertised while the failures are seldom reported. Half the number of plates in such a climate would be more certain to yield success if very carefully packed than twice the number of films.

Only the common and boldest birds came down to the tin of water to drink and be photographed. Of these a species of Bulbul,** a bird a little larger than a Robin, with a black head, a brown back, and a white breast, was the most confiding and usually the first to try the experiment. One or two of these birds were always in the trees over our camps, and their pleasing flute-like notes, almost exactly syllabled by the words "tit-willow," were continually to be heard.

** Pycnonotus arsince (Hempr. et Ehr.). 


\section{CAIIPING AND COLLECTING.}

$W^{\text {thes }}$

HILST travelling up the river we had noted different places where the country seemed most suitable for birds, and for making collections. Arriving at such a spot on our return journey, if satisfied with our former choice, we selected the shadiest tree available under which to pitch the tents, and setting our "trusty" followers to work, we soon had a camp neatly arranged and in working order. While one of us remained in camp, the other two sallied forth to the hunt.

Most of our work was done between five and eleven in the morning. From eleven to three we rested in the shade, and from three until sunset we were collecting again. But the morning hours were generally the most profitable, the afternoon being hotter and often spoilt 
by a sandstorm, while in the evening a necessary slaughter of pigeons for the pot usually had to be undertaken. When out collecting each of us was accompanied by a man to carry the birds, and perhaps a spare gun and a water bottle. When five or six birds had been shot the man was sent back to camp with them so that no time should be lost in the skinning, and as decomposition often set in within two or three hours after death, we found this plan necessary as well as convenient. For carrying the birds we employed a stick, to which were tied at intervals pieces of thread, a space being left in the middle of the stick for the hand. To one end of each piece of thread was tied a small bit of cork and to the other a pin. When a bird was shot the pin was pushed through its nostrils and into the cork. The bird thus hung free from the stick and its plumage was in no danger of being rubbed and injured. Only one of our men showed any liking to come out shooting. They were not sportsmen. Innumerable excuses were invented when they were told to accompany us. But excuses were vain-answers could also be invented. Was illness pleaded-pills were administered, a species called the "Livingstone rouser" being most effective, but the man must come. Did a man say that he had lost his shoes and could not walk 
through the thorns, then he must take another's shoes and be quick. We had no mercy, nor had the companions of the malingerer. They laughed like children when an excuse was silenced.

As is always the case, or at all events wherever I have collected, certain birds, and generally the common ones, interfere with the collecting of others. We were much annoyed by a species of babbler* of about the size of a blackbird, and of a light brown colour, but with a white head, which was lucky for us, as it made them conspicuous and thus easier to avoid. They were common where the trees and bushes grew thick, and were always in small companies. When we were unfortunate enough to come suddenly upon one of these companies the babblers seemed to go mad-whether with rage or terror I never could determine, and assailed us with an incessant stream of the hoarsest alarm-notes. This noise, for it can be called nothing else, was made up of a number of "churrs" so rapidly repeated that the whole sounded like a policeman's rattle turned with feverish anxiety. Moreover, the birds performed in company, sitting side by side on a bough and often touching one another. Were you so unwise as to try and drive them

* Crateropus leucocephalus (Cretzschm). 
away they only retired to another bush and redoubled the noise. If you tried to creep away they followed you advertising your presence to every other bird, and it was a long time before you could finally shake them off. Then there were four kinds of pigeons that were numerous and would rush out of a tree which you were carefully approaching, with such a flap that all the other birds took alarm, and a thick tree often contained twenty birds or more. In another way we were handicapped by two little birds, the pallid warbler $\uparrow$ and the lesser whitethroat. $\ddagger$ The majority of the birds in every thick tree or bush were sure to be either pallid warblers or whitethroats. The difficulty was to discover what else the bush contained. Many of the bushes were so thick that it was not until the birds came near the edges that they could be seen. A thorough examination might occupy a quarter of an hour and then perhaps no other birds but these two would be found. A good pair of binoculars is in every way the ornithologist's best friend, and although a glass should not be relied upon to too great an extent in identifying birds, it was of the utmost service in this work. I was the happy possessor of a pair of Goerz's Trieder binoculars. Everyone praises

\footnotetext{
† Hypolais pallida (Hempr. et Ehr.). $\quad \ddagger$ Sylvia curruca (Linu.).
} 
his own glass, but of all those I have tried none has been so good as this glass for my purpose. The power which magnifies nine diameters can be focussed and used perfectly easily with one hand, which is a great advantage, the definition is excellent, and although the "field" is not large, the glass is so light that it can be moved about quickly and with a little practice even a flying bird can be "picked up" immediately,

In this country of dense bushes and tame birds a knowledge of the notes of the birds was most valuable and a great saving in time. By a systematic identifcation of the performers all the commoner notes were quickly learnt, and then an unknown or doubtful sound proceeding from a thick bush at once drew attention. By means of their notes many of the rarer and smaller birds we obtained were first detected. For instance, one day I had got to the fringe of the wooded tract of country and had reached the beginning of the desert when I heard the sweetest possible little note proceeding from a thorn bush. The bush, although quite leafless, was so thick with green shoots that I could see no bird in it, but the note was so soft and delicate that I knew it must have been uttered by a tiny bird. I went some paces away and waited. After a time four or five most 
elegant little bush warblersई appeared on the outside of the bush. Most refined little birds they were with charming actions. They moved quickly and gracefully from twig to twig, and often fluttered to the ground in their search for insects, and except when actually flying they were incessantly flirting their long tails from side to side with a quick, jerky but dainty motion. We afterwards found these little birds in the acacia trees bordering the desert, and heard their warbling song, which was so soft that a near hearing and perfect silence were necessary for it to be fully appreciated.

In some cases, however, neither our glasses nor our ears were of any service in determining the species of a bird. Two birds which we obtained I thought at the time were reed warblers, $\|$ but on a comparison at home one of them proved to be a marsh warbler. Both these species come to England in the summer, and here in their breeding haunts their different nests and songs and habits make them perfectly distinct. But the birds we obtained were migrating from their winter abodes, perhaps much further south. Their habits appeared to be exactly

§ Spiloptila clamans (Temm.).

Icrocephalus streperus (Vieill.).

- Acrocephalus palustris (Bechst.). 
similar, they were not in song, nor did we hear them utter even a call note, so that there was nothing to differentiate them except their size or plumage. But in size they are exactly the same, while even with the two birds side by side in the hand their plumage is so

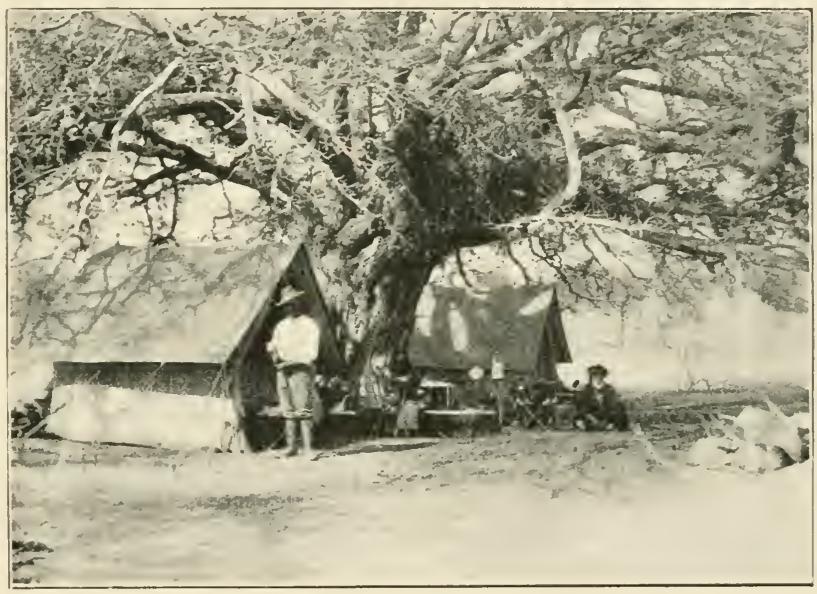

THE CAMP AT DUEX.

similar that no one but an expert would detect the difference.

It was most interesting to come across birds with which one was familiar in England in their winter resorts or on their migrations so far to the south. The extraordinary power of the migrating impulse was brought vividly home to me by the presence of a solitary 
red-throated pipit** feeding on the banks of the river some 1400 miles south of Cairo. Less than a year before I had seen this bird in its breeding haunts beyond the arctic circle in Russian Lapland, and I knew that it only nested north of the tree-limit. When I recalled my own journeys by boat and rail round the North Cape and then again down to Khartoum, and looked at the lonely, delicate little bird before me, it was almost impossible to realise that those feeble wings would in a few weeks' time be transporting that tender little body beyond the arctic circle.

I have said that we rested in the heat of the day, but a variety of causes generally kept us busy. There were birds to skin and label and pack, and notes to be written, then a gun was always kept handy, even at meal times, for the unknown birds which would often come unwarily into the tree over our tents and proclaim themselves by their notes. There were sheikhs to be salaamed and interviewed, and then our own followers required much attention. They stole from the natives, who naturally complained, they neglected the animals and the few dutics we were able to put upon them, they were continually drunk with "merissa," and were always

** Anthus cervinus (Pall.). 
quarrelling and threatening one another's lives. All these little affairs had to be enquired into and dealt with during the mid-day "rest." Correction had to be administered usually in the form of the "korbag," laid on with no sparing hand by a companion of the delinquent. But they were accustomed to this, and a more effective form of punishment, reserved for special occasions, was to administer a kick with precision and power as though one were "placing" a goal at Rugby football. This not only hurt and surprised, but had the additional advantages of wounding the dignity of the kicked, and of bearing gratifying results to the kicker. Catering for ourselves and our followers also had to be attended to, and this sort of conversation would often ensue:- "Hassan, why have we no eggs in this camp when there is a village quite close?" "Ah, effendi, dey no buy (sell) eggs in dis billage, all dee people want to make dee chickens."

To sleep during the mid-day rest was somewhat difficult. The temperature in the shade ranged from $100^{\circ}$ to $115^{\circ}$ Fahrenheit during the hot hours. There were also innumerable insects of various sorts in every camp. Ants of several kinds ran over us and bit us in the day time as well as at night. There were mosquitoes, sand flies and small biting beetles in most places, while 
huge hairy spiders and enormous hairless ones of ferocious attitude and powerful jaws often ran about inside our tents, but luckily these never preyed upon us. In one camp we were assailed by a whole army of little bees, which were extremely diligent in building small cocoon-shaped nests of mud in our bedding, boxes and clothes. At night the nests were tenanted by their builders, who resented a disturbance of their hardlyearned rest, and used their stings so freely that we were obliged to search carefully for the nests and burn out the defenders. Large black hornets were numerous, but inoffensive if not molested.

We yearned to catch and train one of the brilliant plumaged bee-eaters, of which there were four kinds in the country, to attend upon us and protect us from these noxious insects. A bee-eater fears no insect. I saw one of a small varietyt† sitting on a twig suddenly dart into the air and catch a great hornet in the tip of its long bill. Returning to its perch with this delicate morsel, the bee-eater crushed it thoroughly by passing it to and fro through its beak and then suddenly swallowed it whole. In our camps furthest to the south white ants were a scourge and their ravages had to be 
carefully guarded against. All the baggage had to be moved and examined two or three times a day, and so quickly do these pests get to work that during a single night any article left lying on the ground will be completely covered with the sandy secretion, under which

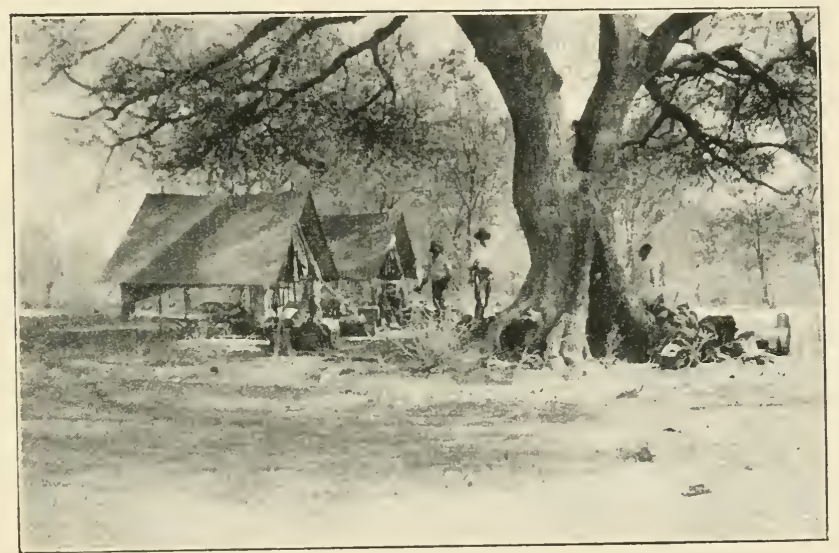

THE CAMP AT GERAZI.

the ants operate, and will be half destroyed. Where white ants were numerous the trees were entirely brown with their workings, and the fallen trunks and boughs were not only brown with the protective covering but eaten through, so that at every step on an apparent mound of earth one crushed through the shell of a fallen tree. 
The most amusing visitors to our camp were the monkeys, which were numerous between Duem and Kawa. They were very tame and used to come regularly into the tree over the tents, and after a tremendous romp, would nestle up to each other and sleep for hours. They were grivet monkeys, $+\neq$ of a beautiful greenish-grey on the back, with whitish breasts, and black faces adorned with handsome white whiskers. We noticed that they were very fond of the gum which exuded from the acacia trees. But mammals of any kind were scarce in the country we worked, and we did not travel far enough south for big game. Occasionally a gazelle or an antelope would be seen, but they were rare and shy. In two or three places there were hares, and it was while I was chasing a wounded hare through some rough grass that I came across the only bird new to science which we discovered. This was a tiny fantail warbler, $\S \S$ of a most delicate light sandy colour on all the upper parts and with a silvery breasta colouring most suitable for the brown grass and sandy country which it inhabited. I only obtained one specimen, and it is somewhat risky to found a new species on a single example, but the Hon. N. Charles Rothschild 
has lately obtained an exactly similar bird near Shendy, so that the claims of my new species may now be considered as established.

The hare was a young one and the only specimen we obtained. Mr. de Winton was unable to refer it to any species already described; but when Mr. R. M. Hawker, in 1901, brought home a mature specimen of the same hare, Mr. de Winton proclaimed it a new species, and named it Lepus hawkeri.

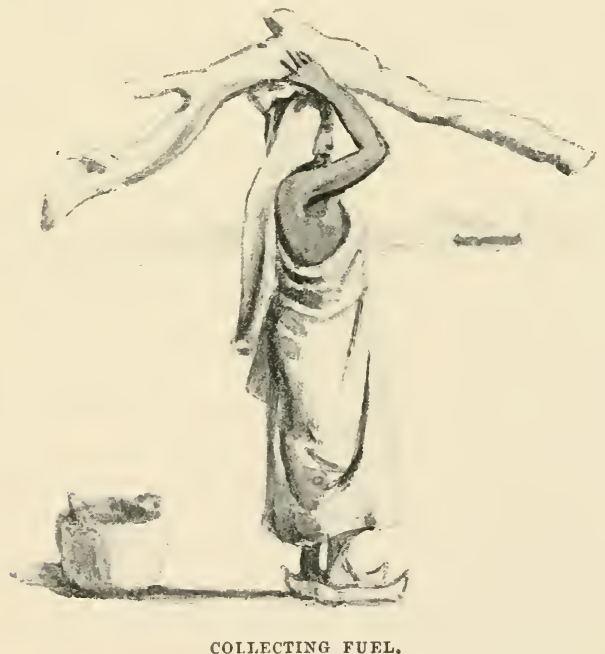

Diaun from a photograph. 


\section{CHAPTER T,}

\section{BIRDS.}

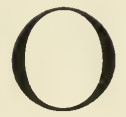

NE of the finest sights in bird-life is that of a falcon taking its prey. Lanner falcons* were fairly common on the White Nile, and several times they swooped down upon sandgrouse which we had winged, and attempted to carry them off. Usually, however, a shout would make the falcon drop such easily won prey. One day when we were riding, a bird rushed over our heads at a terrific pace flying towards the river, which was not more than a hundred yards away. Before we could determine the species of the bird there was another rush of wings over our heads, and looking up we saw two lanner falcons flying side by side. They did not appear to be going very fast, but their pace must have been

\footnotetext{
* Falco tanypterus, Schl.
} 
great, since in the short distance between us and the river, they made up the thirty yards or so between them and the bird they were chasing. Just as they caught it up, one of them shot forward slightly and made a downward swoop like a flash. It then sailed cn along the river's edge, while the other: immediately turned and flew leisurely back the way it had come. There had been no struggle and no uneven movements on the part of the falcon and nothing to indicate that the prey was taken. We could only imagine that the pursuers were disappointed and that they did not carc to continue the chase across the river which the quarry seemed to have reached, but as it had unaccountably disappeared from our sight we could not be sure. The falcon which had made the swoop and was flying along the river's edge settled upon the ground some 200 or 300 yards away from us, and then to our intense surprise, we saw that it had indeed captured its prey in that rapid swoop, and that it was now standing upon it and tearing it. We shouted and fired a shot and the falcon rose, but bore off its prize and would not release it, so that we could only conjecture from the brief sight that we had of it as it was rushing over our heads, that it was a pigeon or a sandgrouse.

Sandgrouse shooting at many points along the banks 
of the White Nile affords such sport that millionaires would give untold gold for were it to be had in England or Scotland. For an hour or more between seven and nine in the morning one can stand behind a bush or sand-hill with a continuous stream of birds passing like rockets backwards and forwards over one's head. Flock after flock comes down from the dry dusty desert to the cool waters of the river. The birds generally stay at the river for but a few moments. Alighting on the edge of the water or often with their feet submerged, they take a sip or two, and then flying up and whirling round, shoot back to their desert home. In some places, however, where broad grassy flats bordered the river, a large number of sandgrouse were to be found all day, and they seemed to live and feed there in preference to the arid inland country. There were two species of these sandgrouse. The majority were of a species $\dagger$ with a sandy-coloured back and a rich dark breast, a bird which is found in astonishing numbers over the greater part of the northern half of Africa. The other species $f$ was decidedly rare and only seen singly or in pairs and never in flocks. It was a larger bird of a less uniform colouring, and with bright yellow throat and cheeks.

+ Pteroclurus exustus (Temm.). $\ddagger$ Pteroclurus senegallus (Linn.). 
Although these birds gave such good sport and were, besides, a very welcome addition to the wiry fowls and an occasional, and always aged sheep or goat which we obtained from the natives, the shooting of them was by no means a pleasure. The great dry heat of the Soudanese summer injured almost everything we possessed, and the effect it had upon the white powder with which our cartridges were loaded produced most trying results. I was told by an expert at home that the extreme dryness of the atmosphere withdraws the moisture from the powder and so causes a too rapid explosion. The fulminate in the cap of the cartridge is affected in the same way, and, as a consequence, all the powder is probably ignited at once, a great deal of gas is generated, and a considerable explosion occurs. The result is extremely uncomfortable and annoying. After shooting 10 or 12 cartridges one becomes quite deaf, and the recoil of the gun makes a painful bruise. Moreover, a strong heavy gun after a time was so damaged as to become dangerous to use. We found that the explosion was much more violent after the cartridges had been carried in the sun for some hours, and also after several shots had been fired in quick succession. Metal and glass exposed to the sun were always burning hot, and after a few shots had been fired quickly a gun 
was too hot to hold with the bare hand. I am advised on good authority that this violent explosion of white powder in a hot dry climate could be prevented by using a small cap and a small charge of powder. A charge of 35 grains of Schulze to one oz. of shot in a twelve-bore cartridge instead of the usual charge of 38 grains of powder would remedy the defect without deteriorating the killing power. But care must be exercised in the loading, and the extra space in the cartridge case must not be filled with hard wads or used for a deep "turn-over," which would tend to keep the powder back and increase the recoil.

Besides the sandgrouse, pigeonsई provided us with many a meal-indeed, too many. So numerous were the pigeons and so thickly did they cluster in the trees that, to save time and ammunition, we often shot from twelve to sixteen with a single cartridge. The pigeons were great drinkers, but unlike the sandgrouse, their favourite hour for imbibing was just before sunset. Sandgrouse also came down to the river just then, but only irregularly and in small numbers. Apparently only the very thirsty individuals drank in the evening as well as the morning. After their drink the pigeons flew

§ Turtur ambiguus Boc. Turtur roseogriseus (Sunder.). 
to a considerable height in the air and then, arriving above their intended roosting place, they suddenly closed their wings and hurled themselves down like stones. Just before the tree-tops were reached they checked their headlong plunge with outstretched wings, and circling round once or twice, alighted noisily in the acacias. In fact this downward plunge to the roosting trees was performed by these African pigeons in much the same way as it is by our wood pigeons at home.

One evening, from the same spot, I fired some twenty shots at pigeons as they were plunging down, and I . noticed in a tree thirty yards away from me a little bittern, || which sat motionless stretched upwards as stiff as a ramrod during the whole cannonade. We saw many little bitterns in the trees in the Soudan, and they generally adopted this stiff and attenuated attitude, which is undoubtedly assumed for purposes of concealment. I have seen the bird in the same attitude amongst green reeds in Spain, but there, as in the acacias in the Soudan, the bird benefited nothing by its strange posture. The little bittern is a creamcoloured bird with a velvety black back and head, and I think it could never be taken for a stick or reed 
except perhaps in broken light. With the browncoloured common bittern, which adopts the same pose, the case would be different. One might suppose, however, that the little bittern itself considered the attitude a complete protection by adopting it on the approach of danger, and by remaining motionless through such a terrifying ordeal as the sound of the twenty shots I have mentioned. Had the bird frequented the thicker trees, its stick-like attitude might have saved it from detection, but in the open trees in which we generally found it the trick was a ludicrous failure.

There were other birds in this country which either by their protective colouring or by their attitudes were rendered inconspicuous and often invisible. Those which relied upon their colour for concealment were, as would be expected, birds of the open country, and their colouring was, of course, like the sand. Of those I have mentioned-various species of larks were difficult to see even when they were flying, the fantail warbler was exactly the colour of sand or dead grass; the sandgrouse was impossible to distinguish at a short distance in the desert, as were the cream-coloured coursers on the sand by the river. The birds living amongst the trees depended upon the thickness of the branches and twigs for concealment, and although there were few trees with 
leaves, it was extraordinary how perfect a protection they were afforded. Even the most brightly coloured birds were hidden in a thick mimosa bush or acacia tree, and most of the shy birds seemed to recognise this fact, and rather than fly away would retire into the thickest part of a tree. Mouse birds or colies, 9 for instance, flew into a tree and disappeared as if by magic. They have a sweet piping note, and often on hearing this sound I used to creep under the tree from which it came and watch these long-tailed parakeet-like birds creeping and climbing as mice in and out amongst the thickly-growing twigs and branches in the centre of the tree. On catching sight of me looking up at them they would give a hurried, rather gasping, pipe, and climb with wonderful dexterity and swiftness towards the outside of the tree furthest away from danger. When all had arrived on the edge they would fly away, softly piping.

Birds of the night are perhaps the cleverest at hiding themselves. Once when strolling round a mid-day camp to escape the groaning of the camels as they were being loaded, I saw what appeared to be a broken piece of bough in a very thick tree. I was struck by its rather

- Colius macrurus (Linn.). 
bird-like shape, but should have passed it had I not the habit of looking with my binoculars at puzzling sights. The binoculars made the stump look still more bird-like, and after walking all round the tree $I$ at last made out two horns, which I knew must come from the head of an owl. I ran to the camp for a gun and fetched my companions, who assured me the thing was only a stump. I fired at it and down fell two owls, while a third flew away. So that the "stump" was in fact three birds huddled up together. They were beautiful Iittle horned owls of a rare species.**

The only other owls we found were a large handsome eagle owl, $\dagger \dagger$ and a white or barn owl. $\ddagger \ddagger$ The latter was rather more spotted on the breast than our familiar English bird, and for this reason Brehm, who collected birds in the Khartoum district many years ago, gave the barn owl of these parts the sub-specific name of maculata. It is remarkable that although the barn owls are spread over most of the world, they preserve so constant a type that, unlike the generality of birds in similar case, they cannot be separated into different species, although their slight variations enable the diligent systematist to divide them into races or sub-

** Scops lencotis (Temm.). $\quad+\dagger$ Bubo lacteus (Temm.). ++ Strix flammea (Linn.). 
species. The fact that the barn owl seldom migrates, and is a more or less sedentary bird, makes its want of variation all the more remarkable. The only bird of this species that we found inhabited the rocky hill,

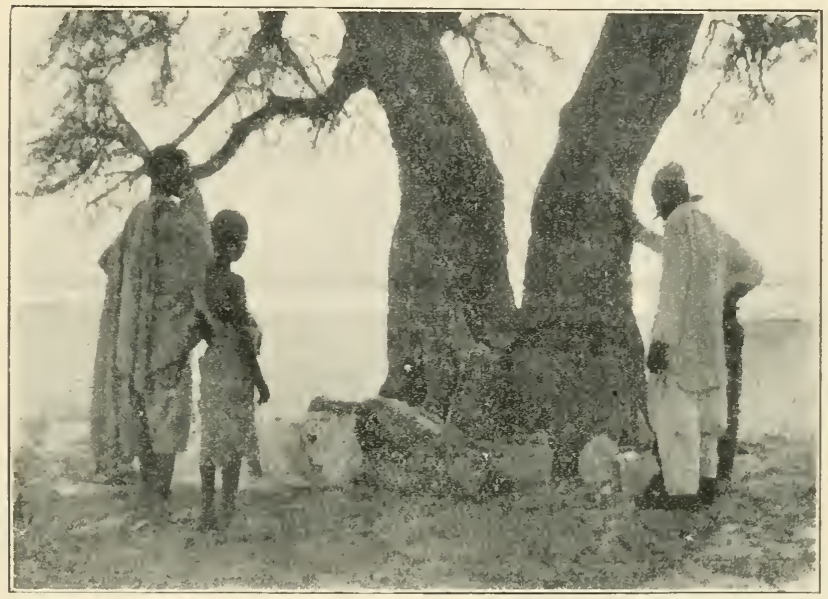

BLEEDING MAHONET.

The doctor adjusting the "cup."

Gebel Auli, which I have already mentioned as the haunt of bats and hedgehogs. The owl seemed to have no mate and lived in a small cavern in the rock. This had perhaps been used as a nesting place, and it was littered with castings of the rejected fur and bones of the bird's prey. 
It was after climbing about this hill and searching its crevices from top to bottom that Mahomet, my stately gunbearer, said he felt very ill and must have a doctor. We considered that he was malingering, but when he told us that he was always accustomed to be bled once a month and had not now had any blood drawn for two whole months, we bowed to his decision and waited eagerly for the doctor. The real doctor of the village of some twenty huts at Gebel Auli was away on a journey, but his locum tenens, who was a decidedly inferior practitioner we were told, put in an appearance. After a long harangue Mahomet decided to be operated on him. The doctor came unprovided with a lancet, but he soon borrowed a razor from Salim, one of the camel men. His only other instrument was a piece of a cow's horn with the narrow end closed by a bit of tin. Mahomet resignedly lay down in the shade, and the operation, the various stages of which we somewhat callously photographed, commenced. The patient's head was shaved and then the cow's horn was placed on the side of the neck. The doctor applied his lips to this primitive "cup" and sucked vigorously until a vacuum was formed, when he closed the opening with the piece of tin. In a few minutes the horn was taken off and revealed a large bump raised on the neck. A 
few cuts were made with the borrowed razor and then the horn was put on again and the blood drawn out by

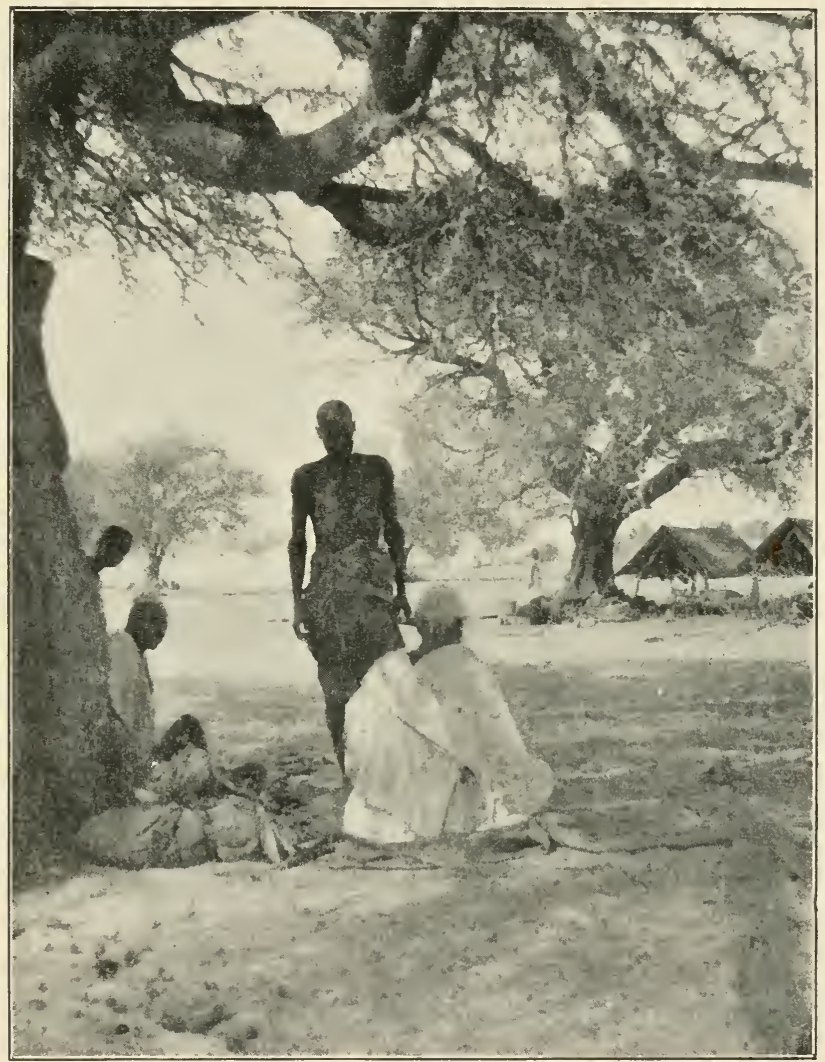

THE "CUP" FIXED ON THE NECK.

the vacuum. By repeating this process seven times on each side of the neck the doctor drew some 5 ozs. of 
blood from Mahomet. The moderate fee of one piastre (2 $\frac{1}{2} \mathrm{~d}$.) was charged, but we were told with some pride that the proper doctor would have charged two piastres. We had always considered Mahomet wanting in blood, but on the morning after the operation he said that he was now perfectly well and we cheerfully believed in the efficacy of the leech.

We rather thought that so primitive a doctor should have a primitive fee, such as an old bottle or tin, or even a bit of cloth, for his own was of the scantiest. But the natives as far as we travelled would take nothing but money. We had provided ourselves with knives, razors and the like for barter, but these would never be accepted as payment although they were demanded, but not given, as baksheesh. Hassan's explanation of the use to which the money was put, ran as follows:- "Dey do put it in hole in ground and ebery six months or year dee faber ob dem do go to next big billage and buy in bazaar all tings for ladies and him and-eberyting." 
7 HE natives, generally, as I have mentioned, took little notice of us. One day, however, when out collecting, we met with a flattering reception from the inhabitants of a small village through which we passed. The mon rushed up to us, seized our hands and kissed them repeatedly; while the women in the background gazed on us admiringly and loudly proclaimed their pleasure with the shrill "sachareet." The "sachareet" is a loud high-pitched trill, sounding like the syllable "la" uttered very rapidly and shrilly, and is used by the Soudanese women on all joyous occasions. We were somewhat overcome and greatly puzzled by this greeting, and suspected that it was due to something more practical than 
pure good nature. The country round the village proved a good collecting ground, and the next day we went there again, and as the place was some distance from our camp we carried luncheon with us. The natives seemed even more pleased to see us than they did the day before. However, as we were bent on collecting, we paid little attention to them, and leaving a couple of men to prepare luncheon in the shade of some thick bushes, we set out to hunt the surrounding country.

On returning in the heat of the day to the temporary camp amongst the bushes we found all the inhabitants of the village engaged in a dance. On our appearance the dance stopped, and our ears were split with the shrill sachareet; the natives crowded round, and we were nearly overpowered by the coarse and pungent odours from the pomades and scents with which the women plaster themselves, especially on festive occasions. Getting the crowd to stand off a little we asked our men the meaning of all this hubbub, and learnt that a wedding was shortly to take place in the village.

We were then led to an open space amongst the thick mimosas, and while the old men and children carefully cleared the sand of the long white thorns, the matrons arranged the scanty clothing of the young girls and made them ready for the dance. All being prepared, we sat down 
on the sand, and the natives arranged themselves in a semicircle in front of us. Behind stood the old women, and in front of them the young men and girls; while the old men and children grouped themselves in various attitudes at each side. Of musical instruments there were none, not even a tom-tom, but time and incentive were given by a somewhat droning chant accompanied with clapping of hands. As yet there seemed no inclination to dance, and a nudging and pushing in the ring of singers indicated unwillingness on someone's part to perform -what woman does not understand the value of coquetry? At length a girl was pushed out of the ring, but she coyly darted back, only to be pushed out again. Then, standing upright for a moment, she began the dance. Putting one bare foot forward and throwing her head right back, with her full bosom thrust out and her hands on her hips, she slowly advanced, swaying from side to side and turning and moving her head in time to the music. Every movement was slow and careful as though the dance were a difficult balancing feat, and the performance reminded one of the strutting and nodding of an amorous pigeon. Behind the girl walked a young man, clapping his hands in time to the chant, while both he and the dancer uttered an extraordinary guttural grunting sound which seemed to 
arise from the very depths of the stomach. The girl stopped in front of us, and still swaying her body, gradually sank down at my feet, then, slowly rising, swished my face with her plaited, grease-soaked hair. Feeling considerably embarrassed, and not knowing what was expected of me, I asked my men quickly to tell me what to do, as the girl was preparing to repeat the perfumed swish. They told me to flick my fingers at her and bend my head to hers. Thankful that nothing more was expected, I did this as well as I could, and immediately all the women set up the shrill sachareet and the dancer returned to her place. Evidently I had done the right thing, but I believe one is also expected to damp a coin and place it on the dancer's forehead. The dance now became more general, several girls performing, and all of us being saluted. A gourd was then brought round and we were told that a collection was bcing made for the bride and bridegroom, who by the way were nowhere to be seen, the bride being carefully locked up until the wedding day, and the bridegroom being too bashful to appear. The gourd so far only contained a few beads. We contributed the little money which we had about us, but felt that the wedding presents were meagre. Our men gave nothing, although they immensely enjoyed the dance. Moreover, when 
pressed, they swore repeatedly and solemnly that they had no money.

These dances are kept up night after night for a week or so before a wedding. John Petherick, in his "Egypt, the Soudan and Central Africa," mentions that jars of merissa are supplied free to entertain the wedding guests. Our men told us that merissa was to be had in plenty during these times of gaiety, but that the visitors had to pay for it, and the knowledge of this fact and the handing round of the begging bowl somewhat detracted from the wild freedom of this primitive scene.

There are many curious customs in connection with marriage amongst the Soudanese. One of a primitive and savage nature was brought to our notice continually. At almost every camp young men were conducted to us to exhibit with great pride long raw wounds on their backs. In every case these wounds were made with the korbag and were inflicted at weddings. Part of the ceremony consists in the bridegroom standing erect and motionless while one of the party flicks pieces of flesh off his back with this deadly whip. Should he move or betray any sign of pain he is considered no man, everyone jeers at him and a crowd of contemptuous hags rush on him, their nails proving often worse to endure than the liorbag. 
For two hours after we had got rid of the dancers an almost overpowering smell of ointment hung heavily in the air, and we were only too glad to cut short our mid-day rest and resume collecting. Hearing at some distance a loud wild whistle somewhat like that of a buzzard, I followed up the sound and tried to get near the bird that made it. But it was a long chase. The country was fairly open and the bird very shy, so that it easily managed to watch me and with heavy dipping flight to keep well out of range. At length, however, a wooded place gave me the advantage, and after a short stalk I secured the bird, which proved to be a darkcoloured hornbill.* Most of the hornbills, as is well known, are characterised by an exceedingly large bill, the upper part of which is thickened to such an extent as to form a sort of casque, and the whole is usually brilliantly coloured. The bird I had just secured had a large heavy curved bill, but the casque was small and scarcely noticeable, while in colour the bill was black. A smaller species $\dagger$ of hornbill, which was fairly common in the district, also had a comparatively slender bill, but coloured more brightly with red, black and yellow.

These curious birds were, unfortunately, not breeding

* Lophoceros nasutus (Linn.).

$\dagger$ Lophoceros erythrorhyncus (Temm.). 
at the time of our visit, so that we were unable to observe the remarkable habits, shared, I believe, by all the hornbills, of imprisoning the female in the hole of the tree in which the eggs are laid. When the female begins to sit the male proceeds to plaster up the entrance to the nest with a gummy secretion, and his mate is no unwilling party to this arrangement, for she actually helps him in the work. It is probable that while she is sitting she loses all her wing feathers and is thus incapable of flight. If such be the case her prison may well become a fortress, where she is safe from the attacks of monitors and other enemies. A crack is left open in the plaster door and through this the male feeds the female and the young. Even more remarkable than the imprisonment of the female is the fact discovered by the late A. D. Bartlett, that at a certain period of the year hornbills cast the lining of their gizzards. The lining is formed by a secretion, and takes the shape of a bag, the mouth of which is closely folded. When cast up the bag contains the fruit which the bird has been eating, and it is supposed that this process enables the male to provide his mate more easily with food.

The pursuit of the hornbill had led me far from the camp, and the keenness of the chase had made me oblivious to a dark heavy cloud on the horizon. I knew 
well what the cloud meant. It drew rapidly nearer and I walked quickly on, but was still some way from the tents when there was a sudden roar of wind, then fell darkness, and the air, laden with sand, became blinding and suffocating, blotting out the country like a thick mist. To try and proceed meant losing oneself in this fog of sand. To face the wind was to court blindness, and there was nothing to be done but to crouch down back to the driving cutting sand and wait for the storm to clear. Gradually the air got clearer, and with the darkness gone, but with much sand still blowing, I made my way to camp. The storm produced the usual uncomfortable results: clothes and body seemed saturated with grit; boxes and trunks, ever so tightly closed, were filled with sand, and meat and drink that night were thickly seasoned with it. When a storm was accompanied by a heavy rush of wind the results were more annoying. Clothes and papers were scattered, and once my tent blew down with a run, burying my camera and myself in the ruins. The only benefit bestowed by a sand-storm was an occasional cool wind which followed, but this was, unfortunately, rare, and scarcely compensated for the two or three hours of misery the storm cntailed.

As a rule an approaching dust-storm appeared merely 
Dust Storms. A Fine Spectacle.

as a thick murky cloud, but once from the top of Gebel Auli we witnessed a storm advancing upon us over the desert like a huge tidal wave. Towering some two or three

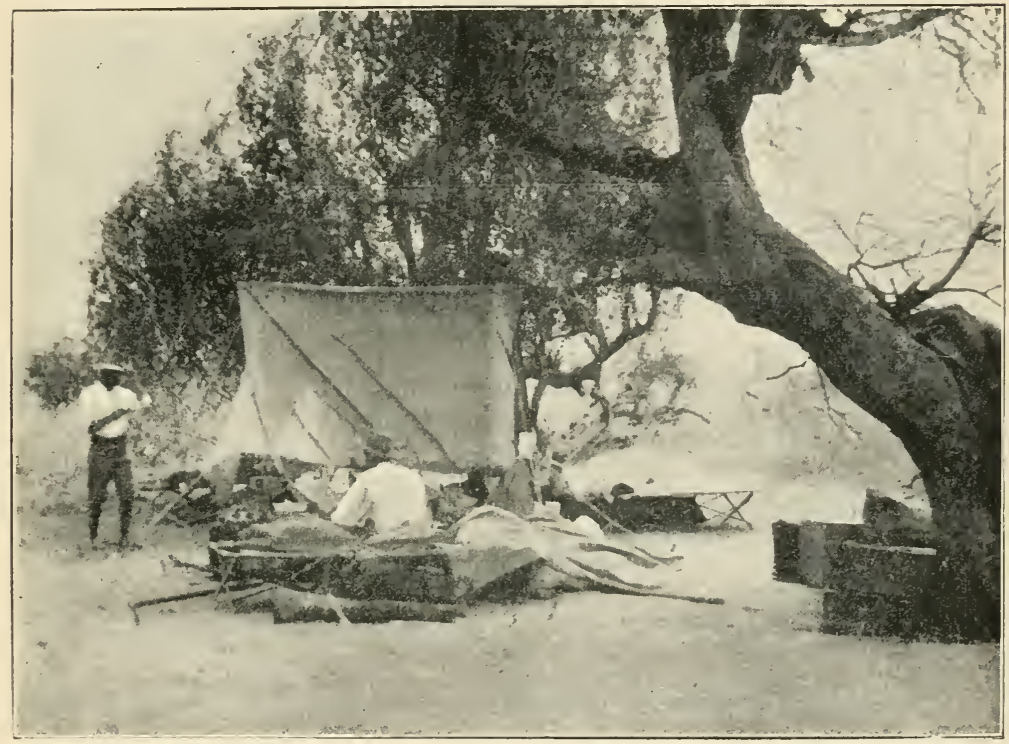

THE TRECK OF A TENT.

Waiting for the Sandstorm to clear.

hundred feet in the air, and stretching away almost to the horizon on either side, the great wave curved like a gigantic bow. Its centre was a shapeless mass of inky blackness, but where the bow curved and the brilliant sun lighted up the wave in profile, its form was as 
compact, well defined, and rounded as any Atlantic breaker, and its colour of a rich deep yellow. Rolling over and over and advancing slowly but certainly, it seemed as though it might sweep everything from the face of the earth. In front all was bright and peaceful, behind all was dark and gloomy. Suddenly we heard the roar of the wind, a few moments more and the wave was on us, its outline faded and we were engulfed in the thick darkness and driving sand. An hour or two afterwards we emerged from the shelter of a rock and made our way to camp, and all that night we slept in a wind that was delightfully cool but heavily charged witl sand. Sand-spouts, dust devils, or "cock-eyed-bobs" were other forms of sand-storms which caused us much amusement. A little whirlwind suddenly starts in the desert raising a small column of dust. The column whirling spirally upwards rapidiy increases both in height and circumference. Then it begins to move along and at length tears madly across the plain as if alive, gathering pace and volume as it goes and whirling aloft every loose thing it encounters. At all hours of the day these spiral columns of sand race over the desert, stopping here and there, then rushing on again. They vary as much in their size as in their direction. Sometimes two will meet each otler, and if they be well 
matched the collision stops them and a struggle ensues as to which way they shall twist. Gradually one gains the mastery, and the two combined begin to gyrate alike and then rush on together. A dust devil comes on you unawares and sweeps off your hat and an Arab's clothes. I have seen one twist a goat round like a top, and our camel-men were once attacked and their loose clothes swept off, while we, only fifty yards away, heard the roar but felt not a breath of wind.

The wildness, the freedom, and the limitless extent of the desert all have their charms, the scent of its heated breezes is fascinating, while its very barrenness has an intense interest. Compare the vegetation of a desert to that of a well-watered country. In the desert the plants fight for life against the want of moisture; they are thinly spread, stunted, with small leaves or no leaves, spiky or hairy, every contrivance being made use of to prevent transpiration and to retain moisture. In the watered country the plants fight against one another, they crowd each other out, and the most luxuriant gains the mastery. In the desert you can read in the sand as in clearest print and see the scarcity of its animal life. Bordering on the watered country the tracks are fairly numerous, but the further you go the fewer become the feet-marks until those of sand- 
grouse and a few other birds with here and there a run of some small animal are all the marks to be seen.

One afternoon while wandering about the fringe of the desert I came upon some tracks made by small birds which seemed to be great runners. I followed up the spoor until it disappeared, evidently where the birds had taken to flight. Going on and casting about I found the tracks again and eventually got a sight of some sandy-coloured babblerst running swiftly along the ground. When I neared them they uttered a shrill "whee" quickly several times, then rose and flew straight and low, alighting some little way off. After hunting them a long time and getting no nearer, I at last drove them into some thick leafless bushes. I could see them from the distance with my binoculars perched in the bushes and flirting their tails up and down like wagtails, but when I got near they had disappeared. Then I heard a shrill note coming from the middle of a bush which was composed of thin and wiry green shoots, leafless but so thickly interlaced that the birds were perfectly hidden. I kicked the bush, but the birds would not budge. I walked all round it several times but the birds only travelled round on the opposite 
side. When I was least expecting it the babblers flew out suddenly and silently, and were hidden in a neighbouring bush before I could get a view of them. By employing dodging tactics somewhat like hunting a person round a table I managed to secure two or three specimens.

The chase ended, I began to realise that six or eight miles of desert divided me from the river; that I had no water bottle and was parched with thirst. The east grew dark, and turning round, I saw the sun quickly dipping below the horizon. I hurried to the river but had not gone a mile before the sun sank, and the light rapidly drawing itself together, plunged down after it, the landmarks disappeared, and I was left without a guide. I trudged on and luckily kecping my direction fairly well, at length reached the trees. After a long search I found the camp, but was then nearly speechless with thickened tongue and parched-up throat. Such a condition was uncomfortable enough, and gave one a slight idea of the agonies suffered by those who die of thirst in the fiery heat of the desert.

The chief object of this walk in the desert was to search for a rare and beautiful goatsucker.§ Only four 
specimens of this bird were known and they had been brought home many years ago; three by Rüppell and one by either Schimper or Baron von Müller. The exact. locality from which they came was uncertain, but it was known to be from somewhere in the Sennaar district. Consequently the bird was one of our possible prizes and was hunted for accordingly. The plumage of the head and back of this lovely goatsucker is like burnished gold with small spots and bars of black and grey, while the breast is buff coloured. A bird of such colouring should evidently live amongst yellow sand, but the desert for the most part of the country we traversed was of a gritty grey colour. It was not until we were within twelve miles of Khartoum on our return that we found the desert of a colour to match the goatsucker. But all our search was useless. The goatsucker was not to be found by tramping over the burning sand. Then good fortune came to our aid.

There is just a short half-hour after sunset when the bats begin to fly and one can see to shoot them against the fast waning light in the west. On one of our last evenings of camp life I was trying to shoot some small bats that were flitting round the tents. The first that dropped I failed to find in the darkness, so I marked the place where it seemed to fall by a small pyramid 
of mud. By this time the sun's glow had faded, but a brilliant moon had risen, and thinking I should be able to see the bats flying over the water, I moved down to the edge of the river. As I was standing there a hawklike bird appeared like a ghost from over the river. As it passed me I raised my gun mechanically and fired, but the bird went on and in ten yards or so was out of sight. I thought no more about it as my gun was loaded with dust shot and the bird seemed large and some distance off. Tiring at length of shooting by moonlight I returned to the camp, and calling for a lantern, went to search for the bat at the place I had marked with a heap of mud. As the light flashed on the spot, there lying dead with outspread wings was the glorious golden goatsucker. I picked it up and rushed madly to my companions. The Arabs looked on in wonder at three frantic Englishmen dancing and shouting round a bird. It was one of those rare occasions in a naturalist's camp when champagne would seem a necessity. Having none we drank to the goatsucker in whisky and White Nile water.

That night we heard a goatsucker "churring." We hoped it might be a golden one, but could detect no difference in its note to that of the common goatsucker of the country, which rasped continually like some huge 
locust in the trees about our camps. Needless to say in the few days before we reached Khartoum and began

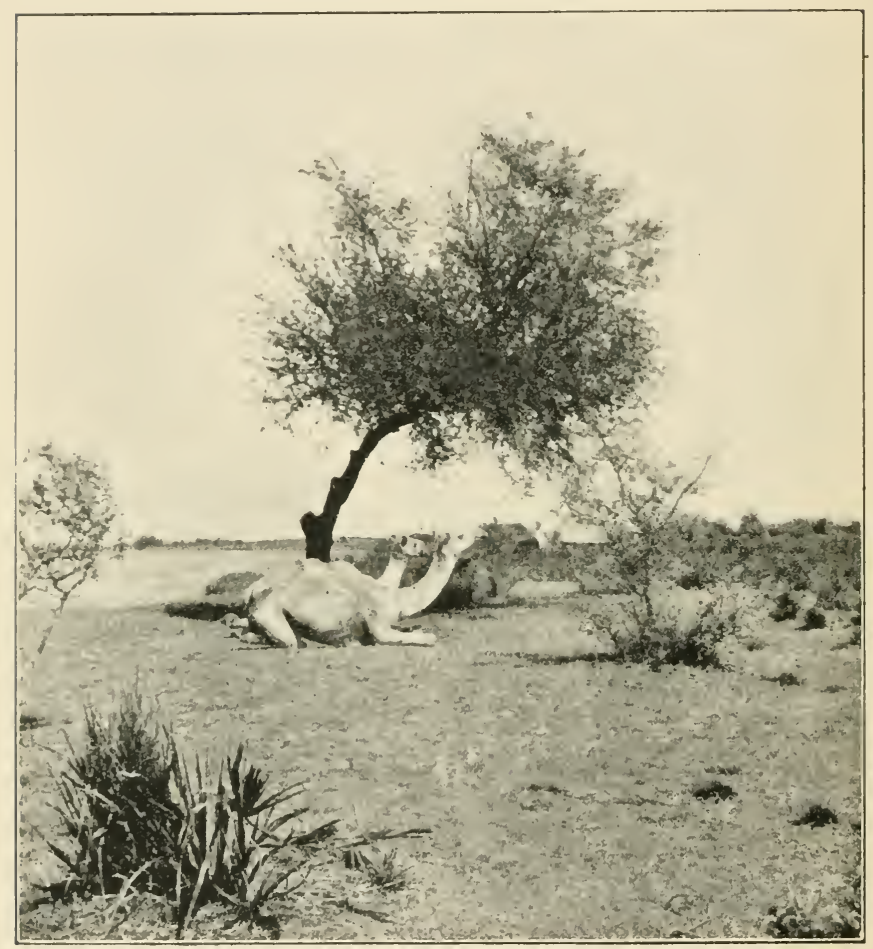

IN THE HEAT OF THE DAY.

our rush home to England, we redoubled our efforts to find more of so rare a bird, but not a sign of another did wo see. In a country made easily accessible by rail 
such a bird cannot be expected to remain rare long, and this year, near Shendy, the Hon. N. Charles Rothschild and Mr. A. F. R. Wollaston found this goatsucker fairly common, and brought home some fifteen specimens.

The fate of the bat that led to the finding of the goatsucker must be told. In the morning I searched carefully and found it. Strangely enough it was of much the same colour as the goatsucker, and on bringing it home Mr. W. E. de Winton pronounced it a new species. Captain Stanley S. Flower, however, afterwards brought home a similar specimen which he had obtained two months before I shot mine, and some 200 miles further to the south. Capt. Flower's specimen therefore rightly took precedence, and the bat has been named Glauconycteris Floweri.

* * * * * * * * * * * * *

I often dream of a broad river flowing through a desert land lit by the bright moon; of a ghost-like form and a chance shot; then I see a stately Arab bearing a lantern, and suddenly the light flashes upon a glorious bird shining like burnished gold all spread out upon the sand. 

List of Birds.

\section{APPENDIX A.}

LIST OF THE BIRDS COLLECTED AND OBSERVED.

No Skins were Preserved of those Marked with an Asterisk.

Nectarinia metallica Licht.

Nectarinia pulchella (Linn.).

EEgithalus punctifrons Sundev.

Motacilla flava Linn.

Anthus campestris (Linn.).

Anthus cervinus (Pall.).

Galerida flava Brehm.

Pyrrhulauda frontalis

(Bp.).

Pyrrhulauda otoleuca (Temm.).

Emberiza flavigastra Riipp.

Passer rufidorsalis Brehm.

Passer diffusus (Smith).

Passer luteus (Licht.).

Serinus leucopygius (Sundev.).
Pyromelana franciscana (Isert).

Edemosyne cantans (Gm.).

Estrilda phonicotis Swains.

Zonogastris citerior (Strickl.).

Sitagra luteola (Licht.).

Hyphantornis galbula (Rüpp.).

Oriolus galbula Linn.

Lamprotornis porphyropterus

Rüpp.

Spreo pulcher (P. L. S. Müll.).

Corvus scapulatus Daud.

*Corvus umbrinus (Sundev.).

Buchanga afra (Licht.).

Lanius senator Linn.

Lanius nubicus Licht. 
Lanius isabellinus Ehrenb.

Lanius dealbatus de Filippi.

Nilaus afer (Lath.).

Laniarius erythrogaster

(Cretzschm.).

Telephonus remigialis Hartl. et Finsch.

Argya acacia (Licht).

Crateropus leucocephalus

(Cretzschm.).

Fycnonotus arsinoe (Hempr. et Ehr.).

Eremomela griseo-fava

(Heugl.).

Cimaroptera brevicaudata

(Cretzschn.).

Sylviella brachyura (Lafr).

Spiloptila clamans (Temm.).

Cisticola aridula Witherby.

Cercotrichas podobe (P. L. S. Miill.).

Acrocephalus palustris

(Bechst.).

Acrocephalus streperus (Vieill.).

Hypolais pallida (Hempr. et Ehr.).

Phylloscopues trochilues (Linn.).

Phylloscopus rufus (Bechst.).

Sylzia nisoria (Bechst.).

Syleia curruca (Linn.).

Aëdon galactodes (Temm.).

Ruticilla phanicura (Linn.).I

Monticola saxatilis (Linn.).

Saxicola aurita (Temm.).
Saxicola melanoleuca (Güld.).

Terpsiphone cristata $(\mathrm{Gm}$.$) .$

Clivicola riparia (Linn.).

Clivicola mupestris (Scop.)

Hirundo rustica Linn.

Caprimulgus eximius Temm.

Scotornis climacurnes (Vieill.).

Coracias abyssinicus Bodd.

Merops pusillas P. L. S. MiülI.

Merops apiaster Linn.

Merops viridissimus Swains.

Merops persicus Pall.

Upupa epops Linn.

Lophoceros nasutus (Linn.).

Lophoceros erythrorhynchus

(Tenım.).

Ceryle rudis (Linn.).

Colizes macrutrus (Linn.).

Cuculus canorus Linn.

Melanobucco vieilloti (Leach).

Trachyphonus margaritatus? (Riipp.).

Campothera mubica $(\mathrm{Gm}$.).

Iyngipicus obsoletus (Wagl.).

Mesopicus goertan (P. L. S.

Turtur communis Selby.

Turtur ambiguus Boc.

Turtur roseogriseus (Sundev.).

Turtur senegalensis (Linn.). 
Chalcopelia afra (Linn.).

Ena capensis (Linn.).

Strix fammea Linn.

Scops leucotis (Temm.).

Bubo lacteus (Temm.).

Falco tanypterus Schl.

* Milvues agyptius (Gm.).

*Haliaïtus vocifer (Daud.).

* Helotarsus ecaudatus (Daud.).

Melierax polyzonus (Rüpp.).

Circues macrumes (Gm.).

* Gyps nueppelli (Brehm).

${ }^{*}$ Neophron percnopternes (Linn).

Ibis athiopica (Lath.).

"Plegadis falcinellus (Linn.).

*Hagedashia hagedash (Lath.).

* Platalea alba Scop.

Herodias ralloides (Scop.).

Herodias bubulcus (Aud.).

*Herodias alba (Linn.).

*Herodias garzetta (Linn.).

* Ardea cinerea Linn.

*Ardea purpurea Linn.

Arretta minuta (Linn.).

${ }^{*}$ Ciconia alba Bechst.

* Ciconia nigra (Linn.).

*Anastomus lamelligenus $\mathrm{T} \mathrm{emm}$.
"Leftoptilus crumenifernus

* Pserudotantalus ibis (Linn.).

* Phalacrocorax africanus (Gm.).

"Pelecanus onocrotalus Linn. Hydrochelidon leucoptera

(Schinz).

*Hydrochelidon hybrida (Yall.).

*Hydrochelidon nigra (Linn.).

Sterna anslica Mont.

* Larus fuscus Linn.

*Phanicopterus roseus Pall.

*Chenalopex agyptiaca (Briss.).

* Plectropterus rueppelli Sclat.

* Dafila acuta (Linn.).

* Dendrocycna viduata (Linn.). Pterochurus exustus (Temm.).

Pterochurus senegallus (Linn.).

*Numida ptilorhyncha Licht.

Eupodotis arabs (Linn.).

Balearica pavonina (Linn.).

${ }^{*}$ Grues cintrea Bechst. Hoplopterus spinosus (Linn.). Octhodromus asiaticus (Pall.).

* Egialitis hiaticula (Linn.).

* Tringa alpina Linn.

*Tringa minuta Leisler

Machetes pugnax (Linn.).

*Limosa belgica (Gm.). 
*Totanus calidris (Linn.).

*Numenius arquata (Linn.).

* Himantopus candidus Bon.

Eidicnemus senegalensis
Pluvzanus agyptizes (Linn.).

*Cursorizes gallicus $\mathrm{Gm}$.

* Glareola pratincola (Linn.). Swains. 
List of MLammals.

\section{APPENDIX B.}

\section{LIST OF THE MAMMALS.}

MONKEY.

Cercopithecus athiops (Skull only).

BATS.

Hipposider'us tridens.

Vesperugo temminckï.

Glauconycteris floweri.

Taphozous perforatus.

Taphozous mudiventris.

Rhinopoma microphillum.

SAND Fox.

Canis pallidus (Skull found in a Kite's Nest).

TACKAL.

Canis sp. (puppy) (Skull found in a Kite's Nest). Striped Pole Cat.

Iitonyx erythece (Skull found in a Kite's Nest).

HEDGEHOF.

Erinaceus albiventris. 
Mouse.

Mus macrolepis.

Field Rat.

Arvicanthis testicularis.

Spiny Mouse.

Acomys witherbyi

Larger Sand Gerbil.

Gerbillus fygargus.

Field Gerbil.

Tatera robustus.

HARE.

Lepus hawkeri. 


\section{N D EX.}

Acacias, 50.

Aetheria, 47.

Animals referred to, 3I, 32, 40, $43,58,59,62,76,77$, I04, I07.

Annoying tactics of certain Birds, 67.

Ants, White, 74 .

Assouan, I4.

Babblers, habits of, 67, 102.

Baggara Quarter in Omdurman, 25.

Bat, a new, 107 .

Bat shooting, I04.

Bats, 59 .

Bee-eaters and insects, 74 .

Bees and Hornets, 74 .

Binoculars, value of, 68 .

Birds and Beasts, regular visits to the river, 40.

Birds and water, 62 .

Birds annoying to the collector, 67.

Birds' notes, 69 .

Birds of Omdurman, 30.

Birds referred to, I3, I6, 30, 40, $44,45,46,47,48,51,62$, $63,64,66,67,68,69,70$, $7 \mathbf{I}, 74,76,78,79,82,83$, $84,85,86,96,102,103$.
Bittern, Little, habits of, $\varsigma_{3}$.

Blood drawing, 88 .

Boats on White Nile, $4 \mathrm{I}$.

Bulbul, tameness of, 64 .

Camel travelling, 37 .

Camp duties, 72.

Caravan preparations, 31 .

Carrying Birds, method of, 66.

Cemeteries, 55 .

Collecting, method of, 65 .

Corn grinding, 57 .

Crane, Crowned, 46.

Crocodiles, 43.

Crocodile Bird, 48.

Crow, Hooded, $\mathbf{r} 6$.

Cultivation on banks of White Nile, 40.

Cupping, 88.

Dance, a Native, 92.

Desert, character of the, 52, IOI, 104.

Desert, life in the, Ior.

Desert routes, 32.

Doctor, a primitive, 88 .

Donkeys, 3 I.

Dove's nest, 5 I.

Dust-devils, 100.

Dust-storms, 98 . 
Eagle, Vociferous Sea-, 44.

Falcon, Lanner, 78 .

Flea, a new, 60.

Game Laws, Soudan, 32.

Geese, 45 .

Goats used for milk, 5 S.

Goatsucker, a rare, I03.

Gordon Memorial College, 22.

Graves, native, 55 .

Greeting, native method of, $9 \mathrm{I}$.

Gun, damage to, Sr.

Gunpowder affected by heat, 8I.

Halfaya, 22.

Hare, a new, 77 .

Hedgehogs, 59 .

Hiding, ways of, used by Birds, 84.

Hippopotami, 43.

Hornbills, habits of, 96 .

IIouses in Omdurman, 26.

Huts and houses, native, 55 .

Ilis, Sacred, 46.

Identification of Birds, difficulties of, 70.

Insects, annoying, 73 .

Journey, plan of, 30,35 .

Khalifa, his tyrannical methods, 61.

Khalifa's house in Omdurman, 26.

Khartoum, 22.

Khors, 38 .

Kites, 30.

Korbag: 43 .

Korosko, 15.

Lark's nest, 5 I.

Licences for arms, 32
Luxor, I4.

Mahdi's tomb, 27.

Marabou Stork, 47.

Marriage customs, 95 .

Migration, a striking instance of Bird, $7 \mathbf{I}$.

Mimosa thorns, 53 .

Money, use of, by natives, 90 .

Monkeys, 76.

Mouse Birds, habits of, $\varsigma_{5}$.

Native dwellings, diversity of, 57.

Natives as collectors, 59 .

Natives, character of, 34, 57, $59,6 \mathrm{I}, 66$.

Navigable extent of Nile, 42.

Navigation, difficulties of, 16 .

Nesting season, $5 \mathbf{I}$.

Nile, the, 15.

Nile, White, banks of, 38 .

Niles, White and Blue, junction of, 23 .

Omdurman, 24.

Openbill Stork, 47.

Oınithologists in the Suludan, I 3 .

Owl, Barn, 86.

Owls, difficulties in finding, 85 .

Oysters, 47.

Palace at Khartoum, 22.

Pelicans, 48.

Permit to travel, 32.

Photographic films affected by heat, 63 .

Photographing Birds, 63 .

Pigeons, habits of, 82 .

Plover, Black-headed, 48 .

Protective colouring of Birds, $\$_{4}$. 
Rafts on White Nile, 4I.

Railway, the Desert, I7.

River, essential to country and inhabitants, 40.

Route from Khartoum to Kawa, 38.

Sachareet, 9r.

Saier Prison at Omdurman, 28.

Sakieh, I 5 .

Sandgrouse shooting, 79.

Sand-spouts, 100.

Sandstorms, 98.

Scenery on the Nile, I6.

Servants, 33, 73 .

Shadoof, 15.

Shrike's nest, 5 I.

Shyness of natives, 56 .

Soudanese troops, 26.

Spinning cotton and hair, 56 .

Square, the Great, at Omdurman, 26.

Stations on the Desert Railway, 20.
Tameness of Birds, 62, 64 .

Temperature, 73 .

Trapping animals, 62 .

Vegetation, 50, 52.

Villages, 54 .

Vultures, 30.

Wady Halfa, I7.

Warbler, a new antail, 76.

Warbler, Bush, habits of, 69 .

Warbler, Pallid, abundance of, 68.

Warblers, Reed and Marsh, resemblance of, 70 .

Water, the value of, 39 .

Weaving goat's hair, 56 .

Wedding ceremonies, 94.

Whitethroat, Lesser, visiting tent, 62 .

Whitethroat, Lesser, abundance of, 68 .

Wood cutting, 52 


